Journal of the Society for the Study of Architecture in Canada Le Journal de la Société pour l'étude de l'architecture au Canada

\title{
The Churches of John G. Howard: The State of Research and Open Questions
}

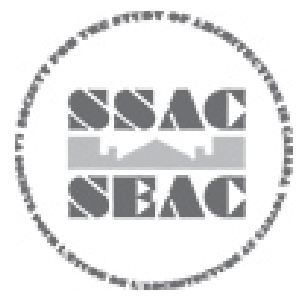

\section{Alana Duggan}

Volume 43, numéro 1, 2018

Religious Architecture in Canada

URI : https://id.erudit.org/iderudit/1049405ar

DOI : https://doi.org/10.7202/1049405ar

Aller au sommaire du numéro

Éditeur(s)

SSAC-SEAC

ISSN

2563-8696 (numérique)

Découvrir la revue

Citer cet article

Duggan, A. (2018). The Churches of John G. Howard: The State of Research and Open Questions. Journal of the Society for the Study of Architecture in Canada / Le Journal de la Société pour l'étude de l'architecture au Canada, 43(1), 17-31.

https://doi.org/10.7202/1049405ar d'utilisation que vous pouvez consulter en ligne. 


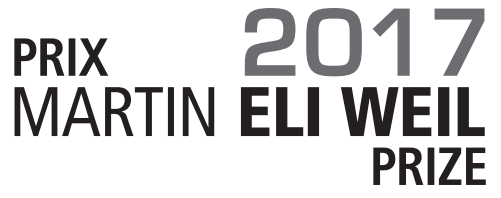

\section{THE CHURCHES OF JOHN G. HOWARD: THE STATE OF RESEARCH AND OPEN QUESTIONS ${ }^{1}$}

\begin{abstract}
ALANA DUGGAN is a Ph.D. student in art history and visual culture at York University, Toronto. Her research focuses on twelfth-century ecclesiastical architecture in the west country of England, and nineteenth-century Gothic and Romanesque Revival architecture in Canada. She is particularly interested in anomalous architectural features and idiosyncratic motifs characteristic of individual architects. She holds a bachelor of fine arts and a master's degree in art history from York University.
\end{abstract}

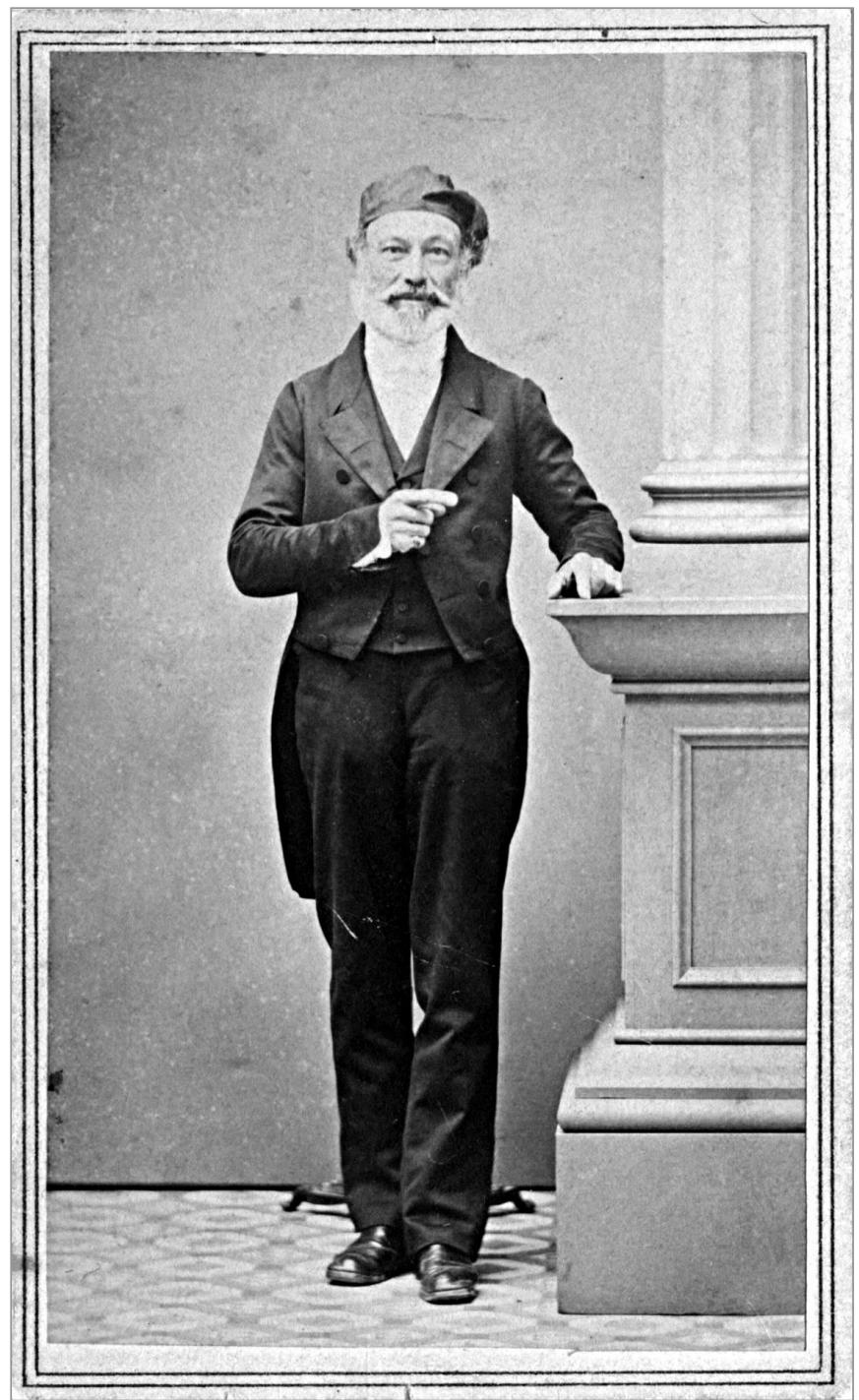

FIG. 1. JOHN GEORGE HOWARD, C. 1860. | COURTESY OF THE TORONTO PUBLIC LIBRARY.

\author{
$>$ Alana DUgGan
}




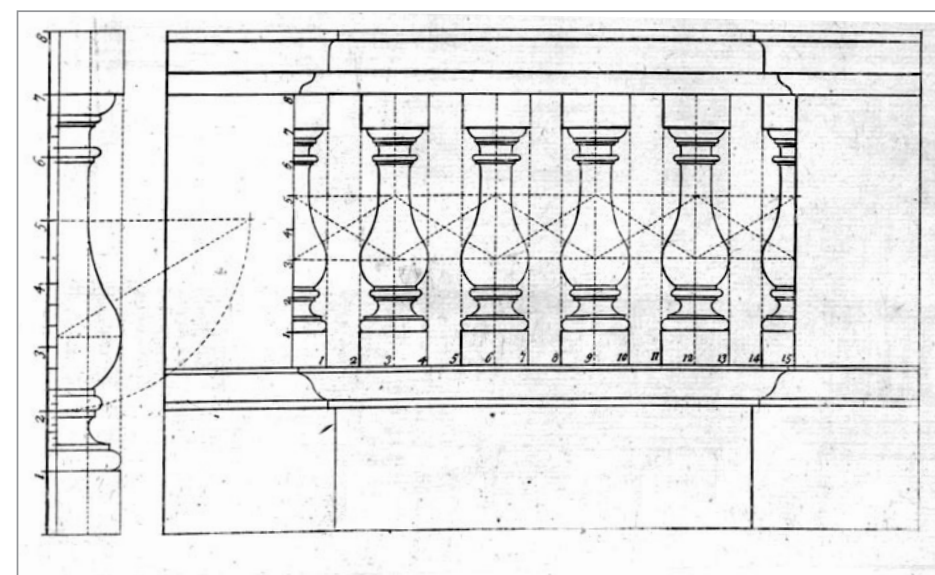

FIG. 2. JAMES GIBBS'S RULES FOR DRAWING THE SEVERAL PARTS OF ARCHITECTURE, 1753, PLATE 67.

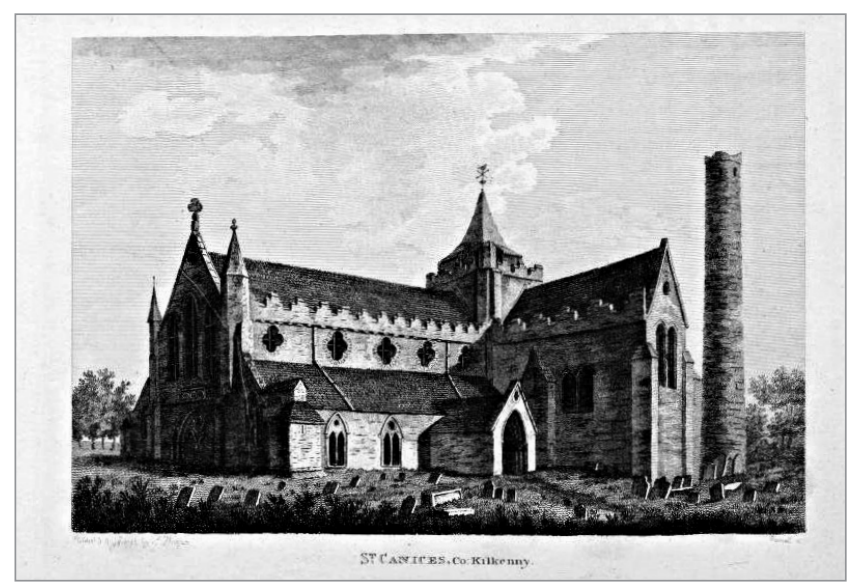

FIG. 3. ST. CANICE, KILKENNY. | FRANCIS GROSE'S ANTIQUITIES OF IRELAND, 1791, P. 32.

\section{BACKGROUND AND INFLUENCES}

John G. Howard (fig. 1) was born John Corby in Bengeo, Hertfordshire, England, in 1803. In 1832, with his wife Jemima, he immigrated to Canada, where he adopted the Howard surname. ${ }^{4}$ He later claimed to be a descendent of Thomas Howard, fourth Duke of Norfolk, and took great pride in this dubious heritage. ${ }^{5} \mathrm{He}$ was appointed first city surveyor by William Lyon Mackenzie and started work as drawing master at Upper Canada College shortly after his arrival in Canada. Despite being one of Toronto's first working architects, Howard soon had competition for commissions with the arrival of Thomas Young. ${ }^{6}$ As was the practice at the time in Toronto (then York), architects had to compete for commissions and that did not always work in Howard's favour. Nevertheless, Howard maintained a thriving business, with over eighteen residential, fifteen commercial, and eleven ecclesiastical projects. The 1840s were the peak of church-building commissions for John G. Howard, but this did not include any cathedral projects despite discussions and drawings to that effect. He kept a daily record of his activities, which exists for posterity in seven volumes of journals, from 1833 to 1845 , and documented details related to his meetings and time spent drawing plans of his various buildings. ${ }^{7}$ They are a useful insight into his daily life and as a log of his productive architectural practice. His self-published memoirs, written in his retirement years, are perhaps less reliable, and sometimes contradict what is written in his journals. ${ }^{8}$ The only churches to make the cut in his autobiography are St. Paul's Anglican Church, Toronto; St. John's Anglican Church, York Mills; Holy Trinity Anglican Church, Chippawa; St. Mary's Anglican Church, Lloydtown; and his commissions for the Indian Department, although he does not elaborate on the specifics of these contracts. This may suggest that apart from those churches he highlighted, his ecclesiastical designs were not his proudest architectural achievements. His donation to the City of Toronto includes, in addition to his journals, his book collection and many architectural and artistic drawings. ${ }^{9}$ Howard retired from his architectural practice, for the most part, by 1855 , and spent his later years at his home, Colborne Lodge, writing his memoirs and working as a forest ranger in High Park. ${ }^{10}$ He died in 1890 at the age of eighty-seven. Besides his architectural legacy, his donation of High Park and Colborne Lodge to the City of Toronto "placed him in the forefront of the city's benefactors." 11

Howard's architectural style was undoubtedly influenced by the tastes of early- to mid- nineteenth-century Upper Canada, and its conservative patrons, who found only the "mildest Gothic flavour" acceptable to their tastes. ${ }^{12}$ The term best applied to Howard's church architecture is Commissioners Gothic, a style that emerged out of "An Act for Promoting the Building of Additional Churches in Populous Parishes . . . 1818," a British initiative advanced by the Church Building Commissioners. ${ }^{13}$ This style incorporated "rectangular-shaped, preaching-box churches of the Classically-inspired architect James Gibbs (1682-1754)" with the additions of Gothic lancet windows and ornament. ${ }^{14}$ Gibbs' Book of Architecture (1728) and Rules for Drawing the Several Parts of Architecture... (1732) were both used well into the nineteenth century. ${ }^{15}$ Howard's churches also demonstrate the low-pitched roofs preferred by Gibbs. The form of vase-turned baluster, favoured by Howard and employed as part of his ubiquitous circular altar rail, may also have been guided by Gibbs's illustrations (fig. 2). 


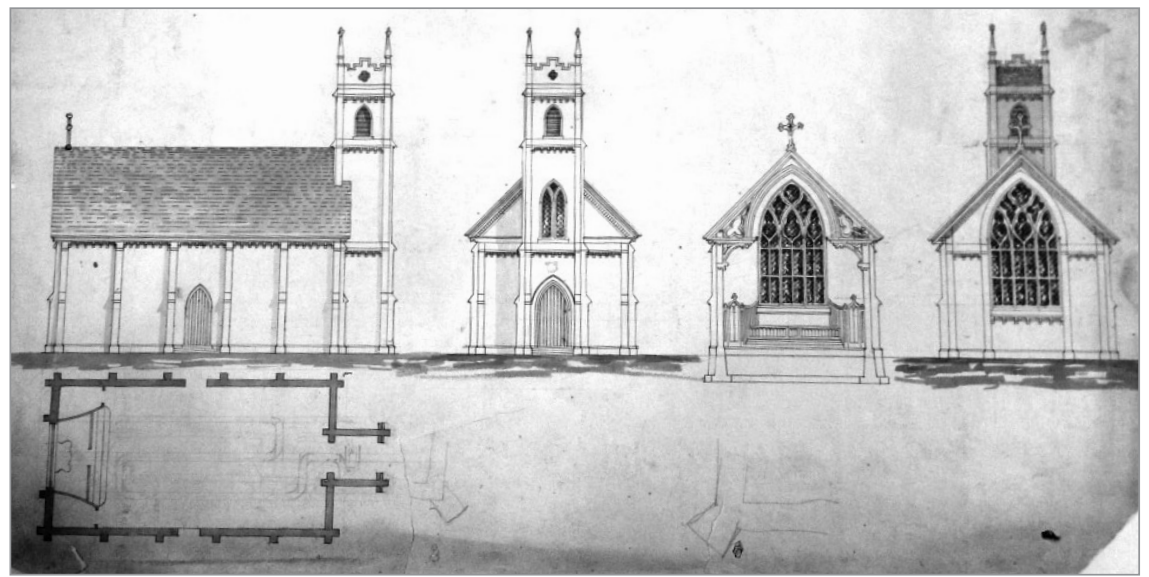

FIG. 4. JDESIGN FOR PRIVATE CHAPEL OF HON. JOHN ELMSLEY, (?)1834. | JOHN G. HOWARD FONDS, TORONTO PUBLIC LBRARY.

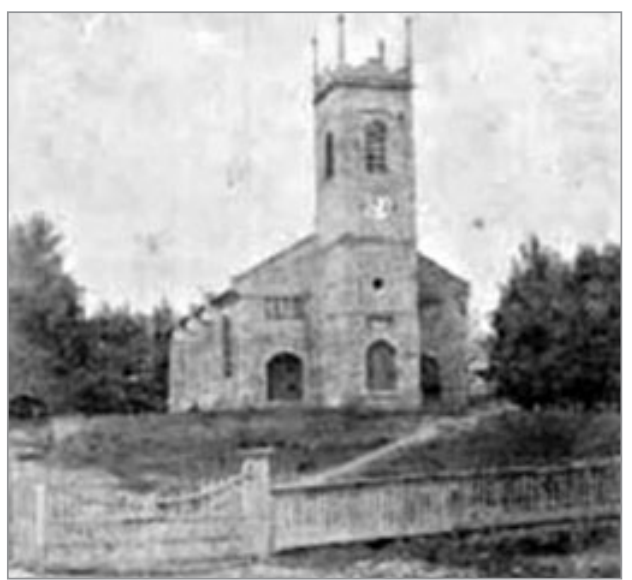

FIG. 5. ST. JOHN THE EVANGELIST ANGLICAN CHURCH, PETERBOROUGH. | [HTTP:/ISTJOHNSPETERBOROUGH.CA].
There is reason to believe that Howard also drew some architectural inspiration from the buildings of medieval Ireland. One of the books in Howard's private collection, which he later donated to the Toronto Reference Library, was the second volume of Antiquities of Ireland by Francis Grose..$^{16}$ In it are illustrations of Irish ecclesiastical buildings, many of which exhibit the regional characteristic of a stepped crenellation on the tower parapet (fig. 3). This Irish motif figures regularly in the church buildings of Howard, and it is quite possible that this text was his source of inspiration.

Influences aside, Howard developed and maintained his own unique archetypal form of church architecture in Upper Canada. This pattern became his modus operandi, which no doubt assisted him in keeping up with his tremendous architectural output, but concomitantly may have limited his ecclesiastical commissions to parish churches. Cathedral commissions were discussed but never realized. ${ }^{17} \mathrm{He}$ favoured a four-bay construction, based on a Gibbsian rectangular box, with a projecting central western tower of three stages defined with bracketed setoffs. Buttresses were often added between bays and on his towers. If the building was constructed in brick, the tower had corner buttresses, and if the church was built in stone, they were diagonal. Frequently these were capped with a gable. Certain Gothic embellishments regularly occur in his church designs, such as foiled tracery cut outs at the top of his towers, stepped crenellations on the parapets, and hood moulds with horizontal termination over pointed windows. His interiors privileged west-end galleries and circular altar rails. Furniture designed by Howard often included carved foiled motifs. These idiosyncratic features provide an instructive guide for identifying a Howard ecclesiastical construction.

\section{0 s}

Howard arrived to York, Canada, in September 1832, and by early 1833 had established his architectural practice, which was "overwhelmed by commissions" since he was the only professional trained architect in town at that time. ${ }^{18}$ In 1833, he helped organize the Toronto Society of Artists and Amateurs under the patronage of Sir John Colborne [17781863] and Archdeacon John Strachan [1778-1867]..$^{19}$ His major non-ecclesiastical projects of the 1830s were the Chewett Buildings (1833), his residence, Colborne Lodge, in High Park (1837), and a jailhouse on the corner of Front and Berkeley (1838, demolished in 1887). ${ }^{20}$ In 1834, York became incorporated as a city and changed its name to Toronto. ${ }^{21}$ The only two church projects attributed to him in these years are not straightforward claims. The first is a private chapel for the Honorable John Elmsley [1801-1863], a building which may not have progressed past the drawing board phase, and the second involved many different architects, making it difficult to determine the extent of Howard's involvement.

There are numerous entries in Howard's journals from November 1833 to April 1834 documenting his work for Elmsley, a prominent figure in York, particularly in the Catholic community, after his conversion to the faith in 1833. ${ }^{22}$ Two projects are recorded for Elmsley, the chapel and a villa, and Howard often did not distinguish between the two in his journal. ${ }^{23}$ Apart from a reference in Hallowed Walls (fig. 4), and the Toronto Society of Artists and Amateurs catalogue, there is nothing to corroborate the attribution of this church, date, and plan to Howard in other sources, 


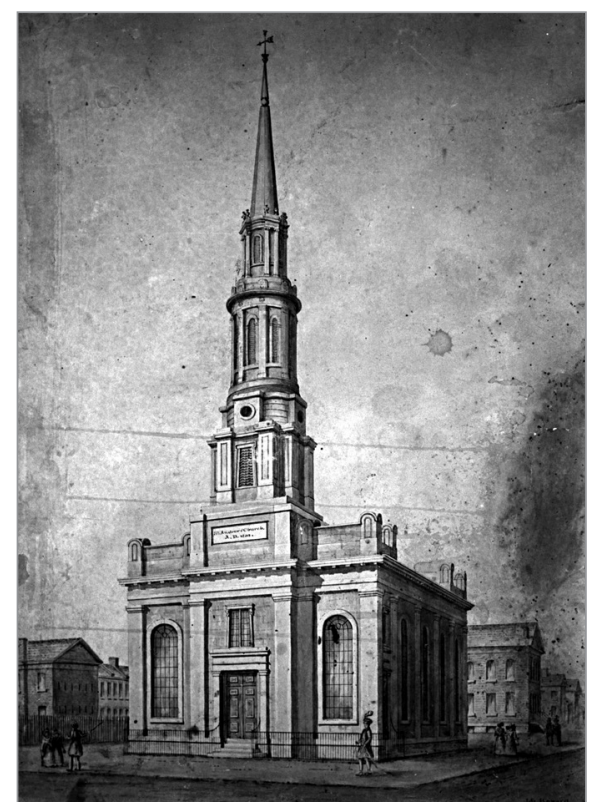

FIG. 6. ST. ANDREW'S PRESBYTERIAN CHURCH, TORONTO, DRAWING BY JOHN G. HOWARD. | COURTESY OF THE TORONTO PUBLIC LIBRARY.

nor is it possible to ascertain a name and/ or location of this church, if it was built at all. ${ }^{24}$ Moreover, it is a very advanced Gothic church design for Howard, most notably in the steep pitch of the roof and the curvilinear tracery of the east window. Nevertheless, this plan does provide an early rendering of some of Howard's trademark motifs: the trefoil plate tracery at the top of the tower and his characteristic stepped crenellation on the parapet. One theory is that Howard's design never came to fruition, perhaps due to the cost, which was reported to be over $£ 12,000 .^{25}$

Canada's Historic Places and Hallowed Walls attribute the early design of St. John the Evangelist, in Peterborough, to John G. Howard, who also recorded in his journals on September 2, 1833, that the plans had been dispatched to Peterborough. ${ }^{26}$ If these were in fact the designs for St. John's, Peterborough, "then in this, his first Canadian church, Howard embarked on the design of

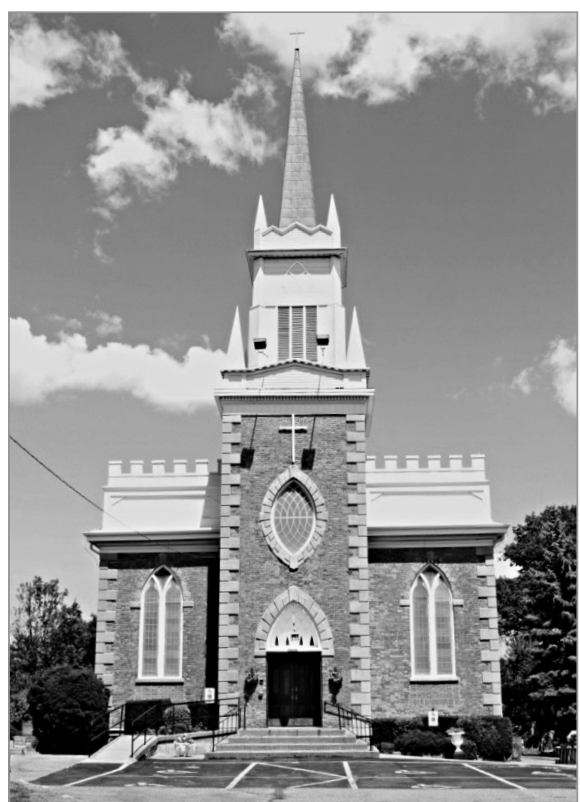

FIG. 7. HOLY TRINITY CHURCH, CHIPPAWA. | ALANA DUGGAN. romantic Gothicism with great caution."27 It is claimed that the church was designed by Howard but revised by William Coverdale [1801-1865], a Kingston-based architect. An earlier picture (fig. 5) on the church website, rather than the current remodelled church, may provide a better idea of Howard's contribution to the design plan. It shows a rectangular box with a projecting central western tower of three parts, and a parapet with the stepped crenellations. Apart from these features, this building does not seem quintessentially Howard, and this may be due to the many other architectural hands involved in its initial execution, and the subsequent alterations over the years.

\section{0s}

These were Howard's most productive years, architecturally, both in secular and ecclesiastical commissions, despite increased competition in the field. ${ }^{28}$ The majority of Howard's churches were built

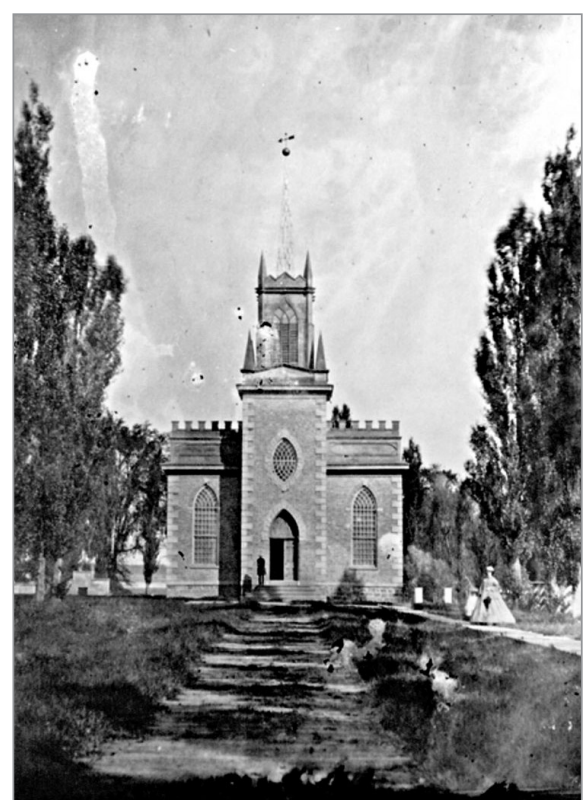

FIG. 8. CHIPPAWA SHOWING THE ORIGINAL WINDOWS AND INTERSECTING GLAZING BARS, C. 1860. | WILRRED HICKS COLLECTION, NIAGARA FALLS LIBRARY.

during this period, as noted, and were Anglican in denomination. Anglican churches of the period "were generally straightforward rectangular buildings with a spire or tower at one end-simplified cousins of the Nova Scotia churches of the late eighteenth century." 29 In 1840, Howard was responsible for the enlargement and addition of a spire on St. Andrew's Presbyterian Church, on the southwest corner of Church and Adelaide streets in Toronto, which was originally constructed by John Ewart in 1830-1831. ${ }^{30}$ The sketch produced by Howard (fig. 6) shows a classically inspired spire, in the Gibbsian tradition, and was likely designed to blend in with the existing architecture.

Holy Trinity Church, in Chippawa, constructed in 1841, one of Howard's most recognized buildings, is also the least representative of his work, as is clearly evidenced from the façade (fig. 7). The explanation for this lies in the fact that the original church was destroyed in the 


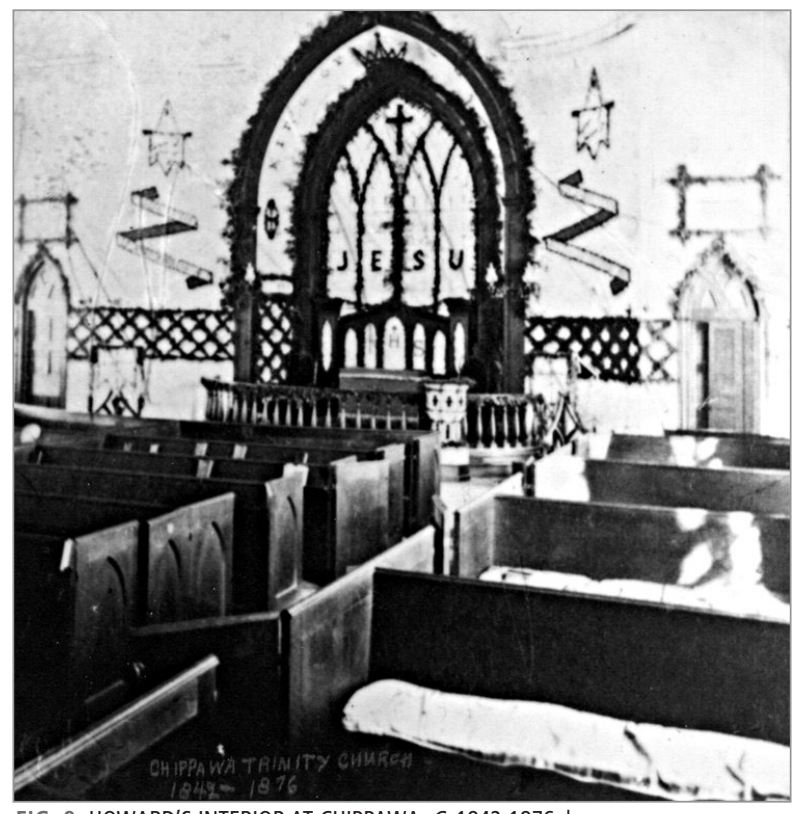

FIG. 9. HOWARD'S INTERIOR AT CHIPPAWA, C. 1842-1876. | NIAGARA FALLS LIBRARY DIGITAL COLLECTION.

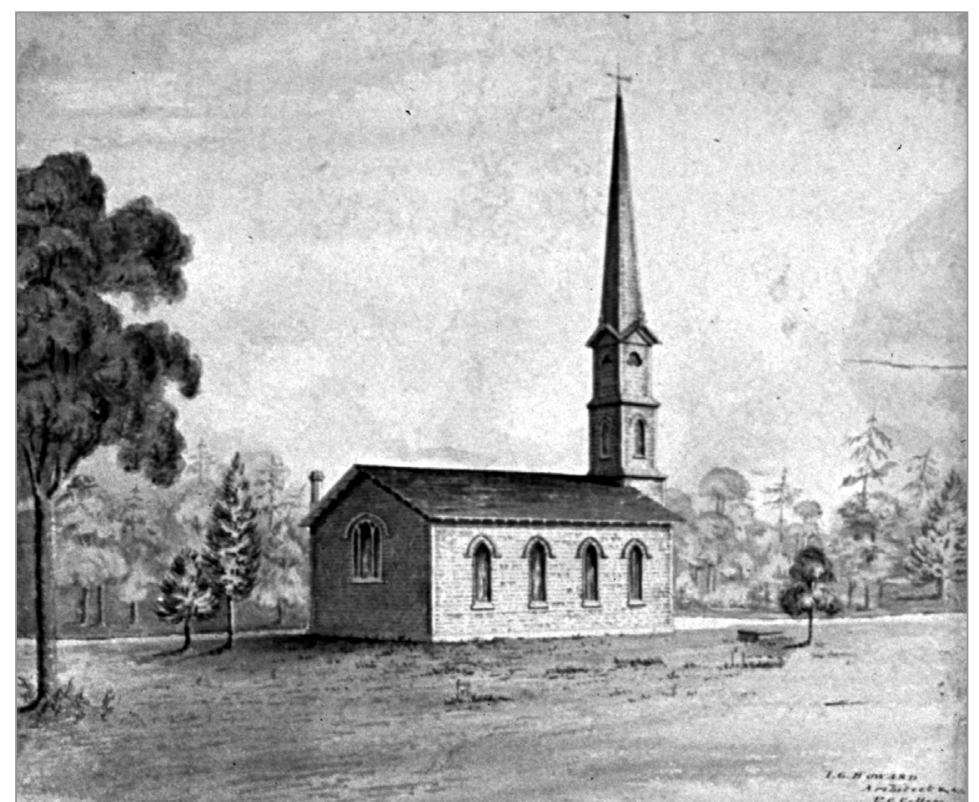

FIG. 10. ST. PAUL'S ANGLICAN CHURCH, TORONTO (NOW DEMOLISHED). | HOWARD FONDS, TORONTO REFERENCE LIBRARY.
Mackenzie Rebellion of 1837, and Howard was requested to design a building reminiscent of the former church. ${ }^{31}$ An earlier image of Holy Trinity (fig. 8) shows the original interlace glazing bar pattern that was typical on Howard's churches. Holy Trinity does follow his usual design layout based on the Gibbsian rectangular plan with a projecting central western tower and four bays, but Howard's inclusion of stone quoins of alternating lengths applied to the voussoirs over the entrance door and around the tower window are unusual embellishments for the architect. ${ }^{32}$ The high panelled parapet, which conceals the low-pitched roof, the ogee arch in the louvered windows of the bell tower, the vesica-piscis-shaped centre window, projecting keystones over the windows and doorway, however, are motifs "derived firmly from the classical tradition," well established in buildings of the $1820 \mathrm{~s}$ and 1830 s in the Niagara region. ${ }^{33}$ The pyramidal-shaped pinnacles used at Holy Trinity, which had been popular in Upper
Canada for more than a decade, had the effect of making the church appear quite "old-fashioned for 1841." 34 The original interior (fig. 9) looking east shows the semi-circular altar rails and vase turned balusters, that Howard favoured, as well as the earlier east window with intersecting glazing bars, which was later replaced with a stained-glass bar tracery version. Howard's interior layout featured two side aisles, which was also later remedied with a more fashionable and "correct" centre aisle arrangement.

Howard's St. Paul's Anglican church (fig. 10), originally located on Bloor Street East in Toronto in 1841, was demolished in 1879. He was most proud of the tower and spire which he erected "in a single day and in absolute silence," so much so that it merited inclusion in both his journal and subsequent autobiography. ${ }^{35}$ Historian Henry Scadding [1813-1901] remarked on Howard's architectural feat: “It was 85 feet high, composed of four entire trees or pieces of timber, each of that length, bound together pyramidically, tapering from ten feet base to one foot at top and made to receive a turned ball and weather-cock." 36 The tower also has a "Howardian" trefoil cutout at the top, just below the spire. The plan follows the usual Howard formula, but is missing the parapet with stepped crenellation.

St. James Anglican Church, in Dundas, Ontario (fig. 11), designed by Howard in 1841, served the Anglican congregation of Dundas until 1925, when a new church was built on Melville Street. It, like St. Paul's in Toronto, incorporates a spire instead of battlements, but the central western tower does not project nearly as much from the nave and is crowned with pinnacles. The windows are not truly pointed but are surmounted with hood moulds that terminate horizontally. Analogues for Howard's design of St. James can be found in John Britton's Architectural Antiquities. Volume 5 (1807-1826). ${ }^{37}$ These 


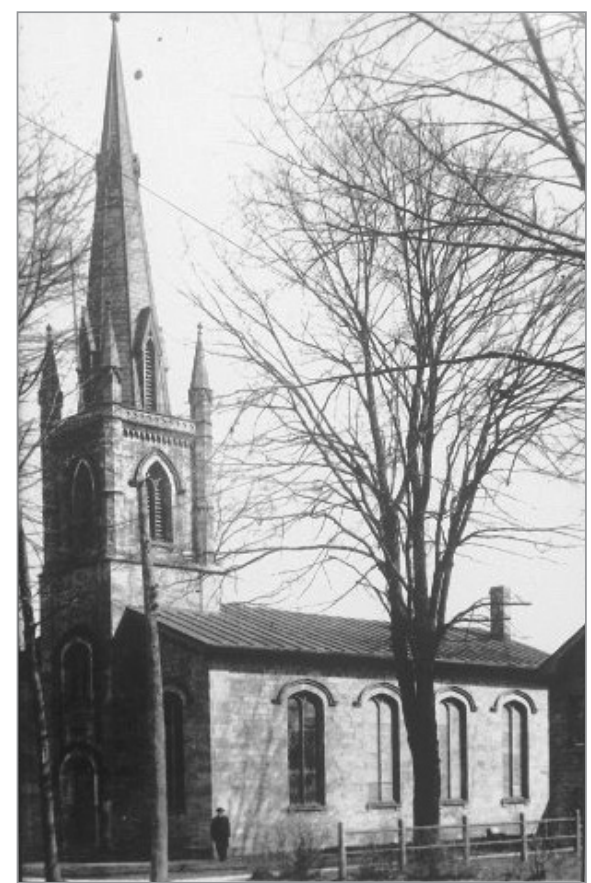

FIG. 11. ST. JAMES ANGLICAN, DUNDAS, HOWARD'S DRAWING OF DUNDAS. | MALCOLM THURLBY HTTPS:IRAISETHEHAMMER. ORG/ARTICLE/1113/JOHN_G_HOWARDS_ST_JAMESS_ANGLICAN_CHURCH_DUNDAS.

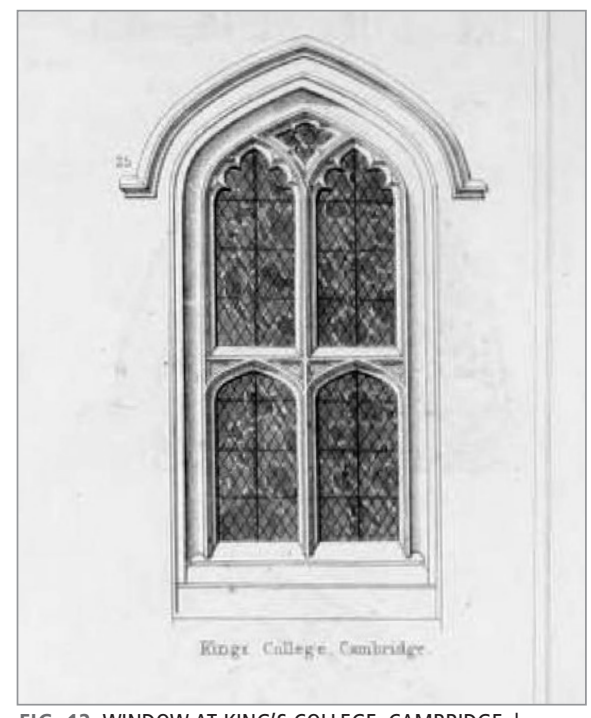

FIG. 12. WINDOW AT KING'S COLLEGE, CAMBRIDGE. | BRITTON, THE ARCHITECTURAL ANTIQUITIES OF GREAT BRITAIN, VOL. 5, PLATES 8384.

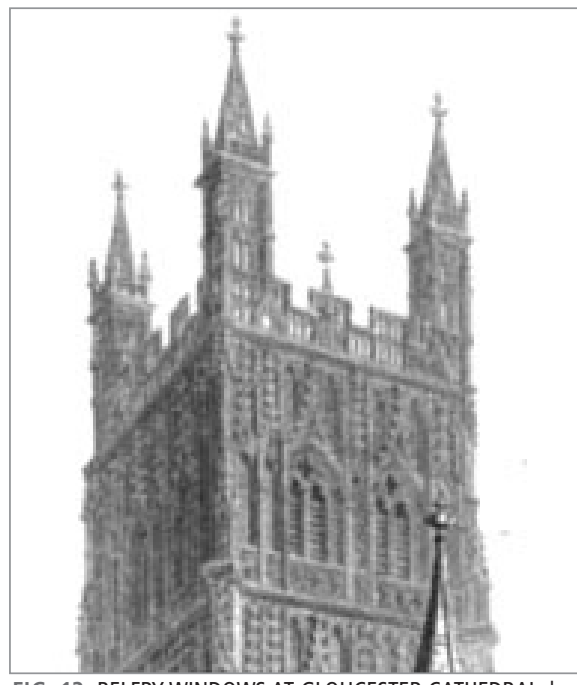

FIG. 13. BELFRY WINDOWS AT GLOUCESTER CATHEDRAL. | BRITTON, THE HISTORY AND ANTIQUITIES OF THE ABBEY AND CATHEDRAL CHURCH OF GLOUCESTER, PLATE 5 .

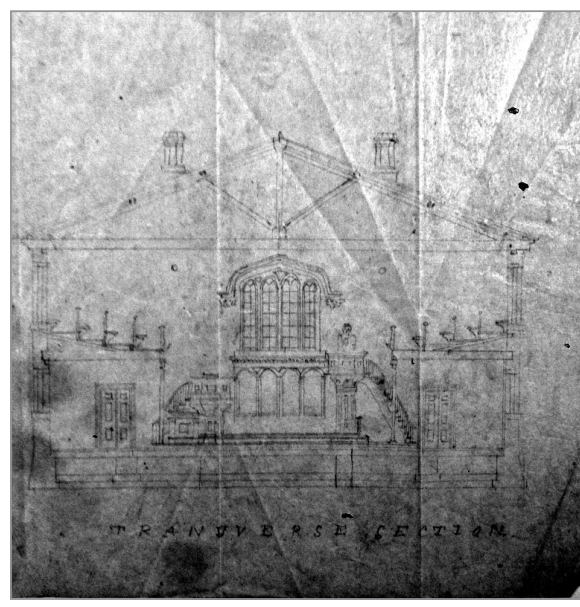

FIG. 15. DRAWING OF INTERIOR PLANNED FOR ST. JAMES, DUNDAS. | HOWARD FONDS, TORONTO REFERENCE LBRARY,

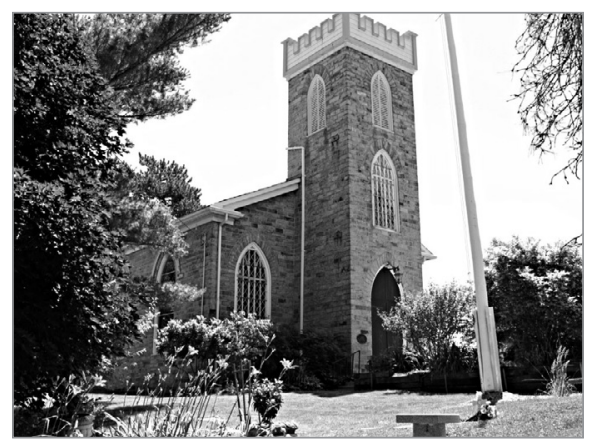

FIG. 16. ST. JOHN'S ANGLICAN CHURCH, JORDAN. | ALANA DUGGAN, 2016.

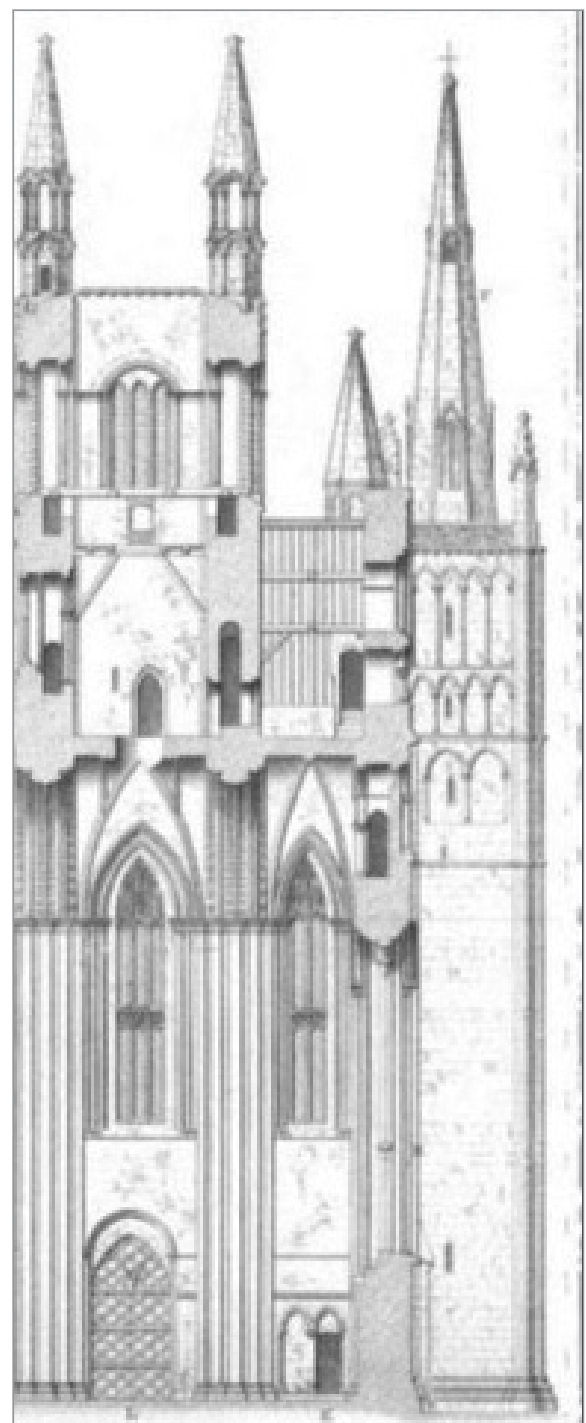

FIG. 14. SPIRES AT PETERBOROUGH CATHEDRAL.| BRITTON, THE ARCHITECTURAL ANTQQUITIES OF GREAT BRITAIN, VOL. 5, PLATE 71

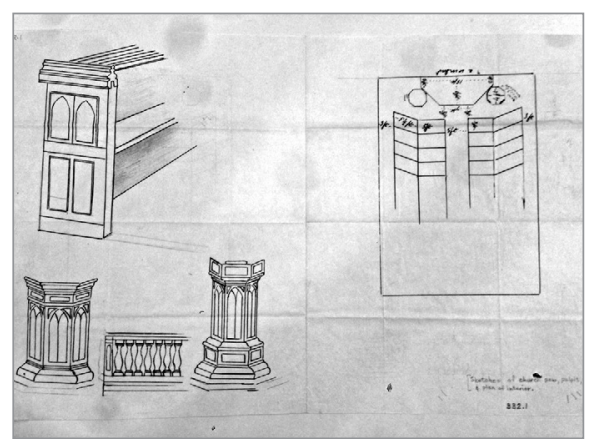

FIG. 17. SKETCH FOR INTERIOR FURNISHINGS AND LAYOUT ST. JOHN'S ANGLICAN CHURCH, JORDAN. | HOWARD FONDS, TORONTO REFERENCE LBRARY. 
include: the window at King's College, Cambridge (fig. 12), as the inspiration for the simplified version at St. James; the belfry windows at Gloucester Cathedral (fig. 13); and the spires on the west front of Peterborough Cathedral (fig. 14). ${ }^{38}$ There is a sketch (fig. 15) showing plans for the interior at St. James, which is all that remains to provide an indication of the original interior. ${ }^{39}$ There is a multi-paned east window over a four-arched panel, most likely intended to display the Decalogue, designed for the Ten Commandments, and common in Howard's interiors. There are a pulpit on the south side, a reading desk on the north, and two east entrances. Side galleries are also indicated in the plan, an unusual inclusion for Howard, who preferred west-end galleries. St. James "would not be mistaken for a medieval original, [but] it, along with most of his other designs, does indicate that the architect espoused principles of Gothic as applied to Anglican Church design in England." 40 The Dundas church was evidently convincing enough for Bishop John Strachan, who declared: "[a] most gratifying sight on entering this flourishing town is the church, built in the modern Gothic style." ${ }^{41}$

Construction commenced in 1841 at St. John's Anglican Church (fig. 16), located on the Niagara escarpment in Jordan. Marion MacRae and Anthony Adamson write: "[t]he vestry records ... did not record the name of the designer of the church (who was probably John George Howard)." 42 The interior furnishings are indeed designed by the architect, as documented in his journals and sketches (fig. 17), and correspond to the extant furniture in the church (figs. 18-19). ${ }^{43}$ Of particular interest are the unusual piers supporting the west-end gallery, which are comprised of four clustered columns, a moulded capital, and a moulded shaft ring (fig. 20). ${ }^{44}$ Remarkably close parallels can be found in the interiors of Howard's

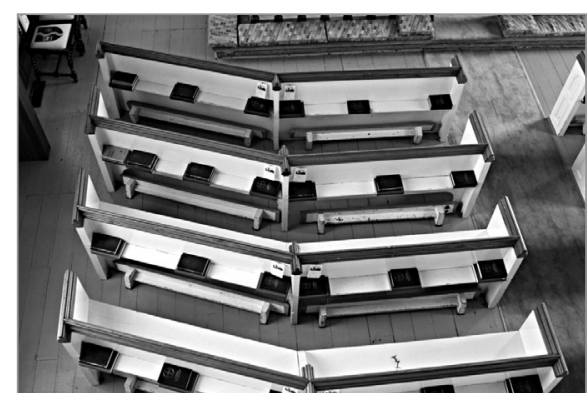

FIG. 18. SEATING LAYOUT, ST. JOHN'S ANGLICAN CHURCH, JORDAN. | ALANA DUGGAN, 2016.

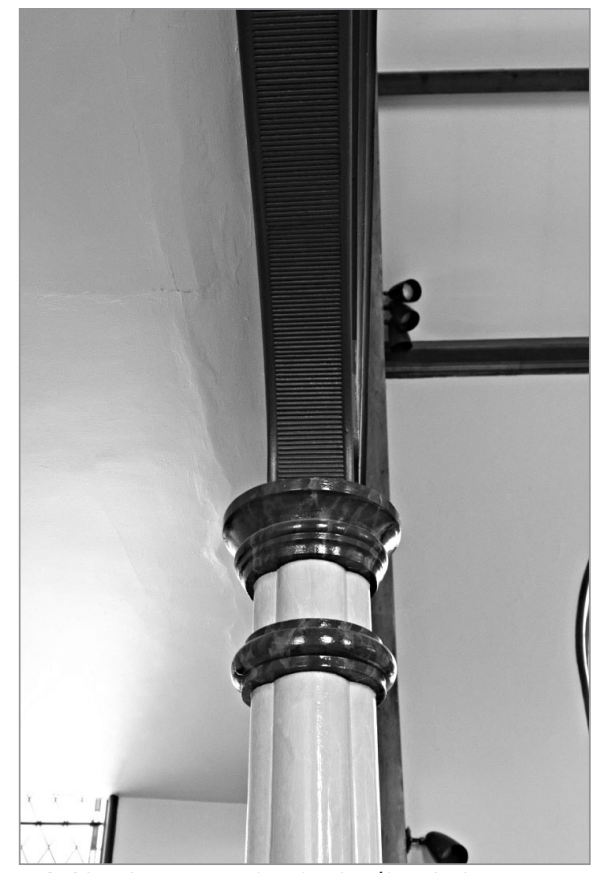

FIG. 20A. GALLERY PIERS AT ST. JOHN'S ANGLICAN CHURCH, JORDAN. | ALANA DUGGAN, 2016.

churches at Snake Island, York Mills, and Tyendinaga. The discovery of a letter from Reverend George Armstrong to Howard, dated July 12, 1843 (fig. 21), both confirms Howard's design of the gallery piers, for a cost of $f 16$ (in addition to other "Gothic improvements"), and disproves the claim that Howard was the architect responsible for the building plans. ${ }^{45}$ It appears the church was built without the services of an architect, a decision which Armstrong later regretted. ${ }^{46}$

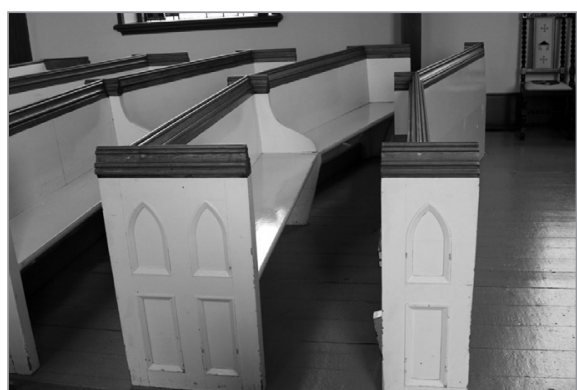

FIG. 19. SIDE VIEW OF PEWS, ST. JOHN'S ANGLICAN CHURCH, JORDAN. | ALANA DUGGAN.

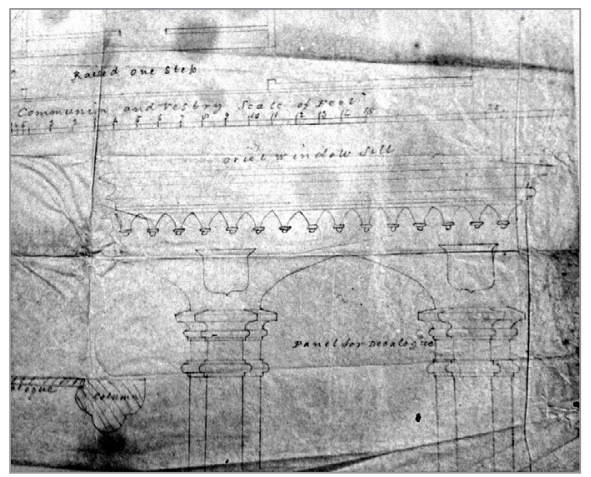

FIG. 20B. DRAWING OF GALLERY PIERS FOR SNAKE ISLAND. | HOWARD FONDS, TORONTO REFERENCE LIBRARY.

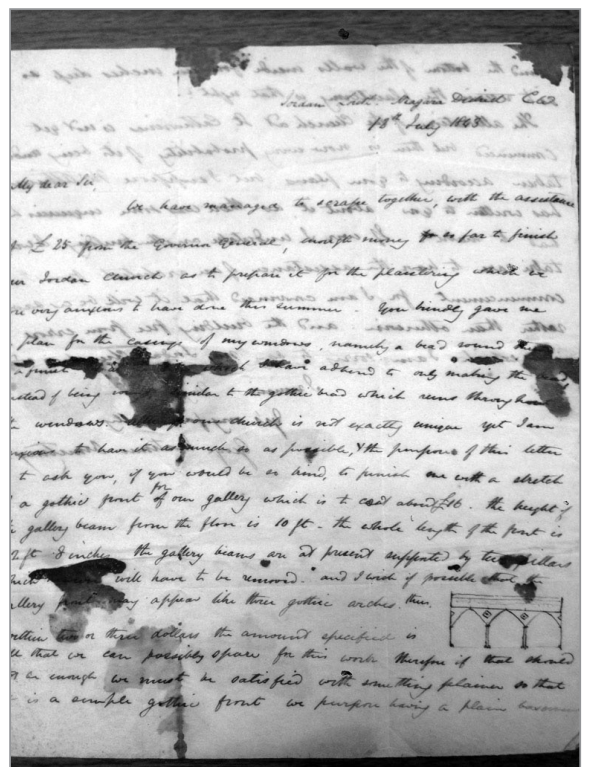

FIG. 21. LETTER FROM REVEREND ARMSTRONG TO HOWARD, JULY 12, 1843. | ANGLICAN ARCHIVES, CHRIST CHURCH, HAMILTON. 


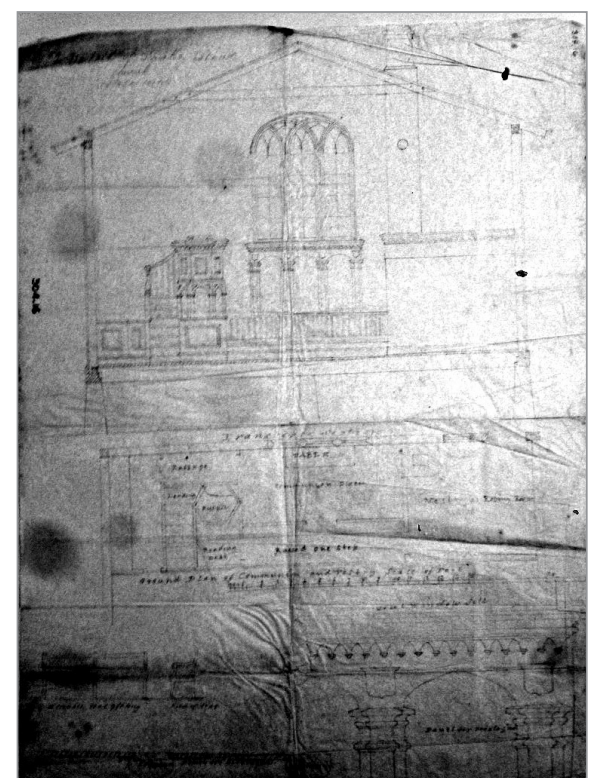

FIG. 22. DRAWING FOR SNAKE ISLAND CHURCH, TRANSVERSE SECTION OF EAST END. | HOWARD FONDS, TORONTO REFERENCE LIBRARY.

In 1842, Howard was commissioned by the Department of Indian Affairs (now Indigenous and Northern Affairs) to design plans for churches and schoolhouses on native lands. This was a fortuitous agreement for Howard, who did not have to compete for these commissions, less so for the indigenous populations for whom they were intended. The locations listed in his journals include: Snake Island, Lake Simcoe, Walpole Island, Lake St. Clair, Manitoulin Island, and Tyendinaga. Apart from Tyendinaga, which is one of Howard's most celebrated churches, these commissions for the Indian Department represent the most murky and least documented set of churches in Howard's ecclesiastical oeuvre; there are many discrepancies and unanswered questions.

One of Howard's few, labeled architectural church drawings, is his design for Snake Island church (fig. 22), a commission he referred to in his journal in March 1842. ${ }^{47}$ The sketch shows a transverse section of the east end of the building, with an oriel window above a Decalogue, as well as designs for deacon's bench seating. Apart from Howard sketch, there are no extant photographs or illustrations of this church. Several calls to residents of Snake Island confirm that no church exists on the island today. Perhaps it was built and later demolished, or never built at all. In a letter to chief superintendent Samuel P. Jarvis [1792-1857], dated October 19, 1843 (fig. 23), Howard writes: "I composed a design for the Church and Parsonage House; the Snake Island church without the spire would have a miserable appearance ... If I understand you right, these two buildings are to be as a pattern for any others that may be required." ${ }^{48}$

Howard's mention of the Snake Island design to be used as a model is, as previously noted, evident in the interior of St. John's, Jordan, although this church was not included in the commissions for the department. Of particular interest in this regard is a template contract document, found at the York Mills Archives, detailing the "Specifications of the sundry Works necessary to be done in erecting a Church at ..." ; there are blanks left for the name of the church, and the patron, adding credence to the theory that Howard relied on an architectural church formula for the various commissions awarded to him.

Perhaps the most contentious location of the mission churches, designed by Howard for the Department of Indian Affairs, is Walpole Island, Lake St. Clair. Howard indicates nothing about this in his journal entries apart from the entry dated July 15, 1842: "Drew plans, specifications and estimates for churches and school houses, and built them, on Snake and Walpole Islands, Lake Simcoe, for the Indian Department."49 The controversy is alluded to in other sources: for example, in Tony Hall's article on native identities: "[a]mong the Anishinabek, Walpole Island remained during the first half of the nineteenth century a centre of considerable Indian resistance against the evangelical inroads of missionary enterprise." 50 Catholic Bishop Michael Power [1804-1847] "recognized that the Walpole Island case called into question whether all Christian churches were being treated fairly by the Crown because, given the evidence presented to him from Walpole, clear favouritism was being shown to Anglicans, Methodists, and Presbyterians." ${ }^{51}$ In his master's thesis on the Walpole Island First Nation, Sheldon Krasowski records that indeed, in 1843, St. George's Anglican church and school were built on Walpole Island, under the authority of the Department of Indian Affairs, but this is not confirmed in the Huron Anglican Diocese, and no supporting documentation exists at the Walpole Heritage Centre. ${ }^{52}$

Howard's journal on June 15, 1842, and an accounting communication between Jarvis and Howard from October 15 that same year, both record a stone church, designed by Howard, intended for the indigenous population on Manitoulin Island. ${ }^{53}$ There is no mention of the location of Wikwemikong, or of the name Holy Cross Roman Catholic church, apart from the footnotes provided by Shirley Morriss. MacRae and Adamson repeat this assertion, likely based on Morriss's research, as does Sharon Vattay in her 2001 Ph.D. thesis. ${ }^{54}$ Contrary to these claims, there are in the archives of both the Diocese of Sault Saint Marie and the Jesuit Diocese of Quebec, documents recording a Nicolas Point as the architect, with the year 1852 as the completion date for this church. ${ }^{55}$ The error seems to be precipitated by the mention of a "stone church" of which Holy Cross is the only one in existence on the island. Further 


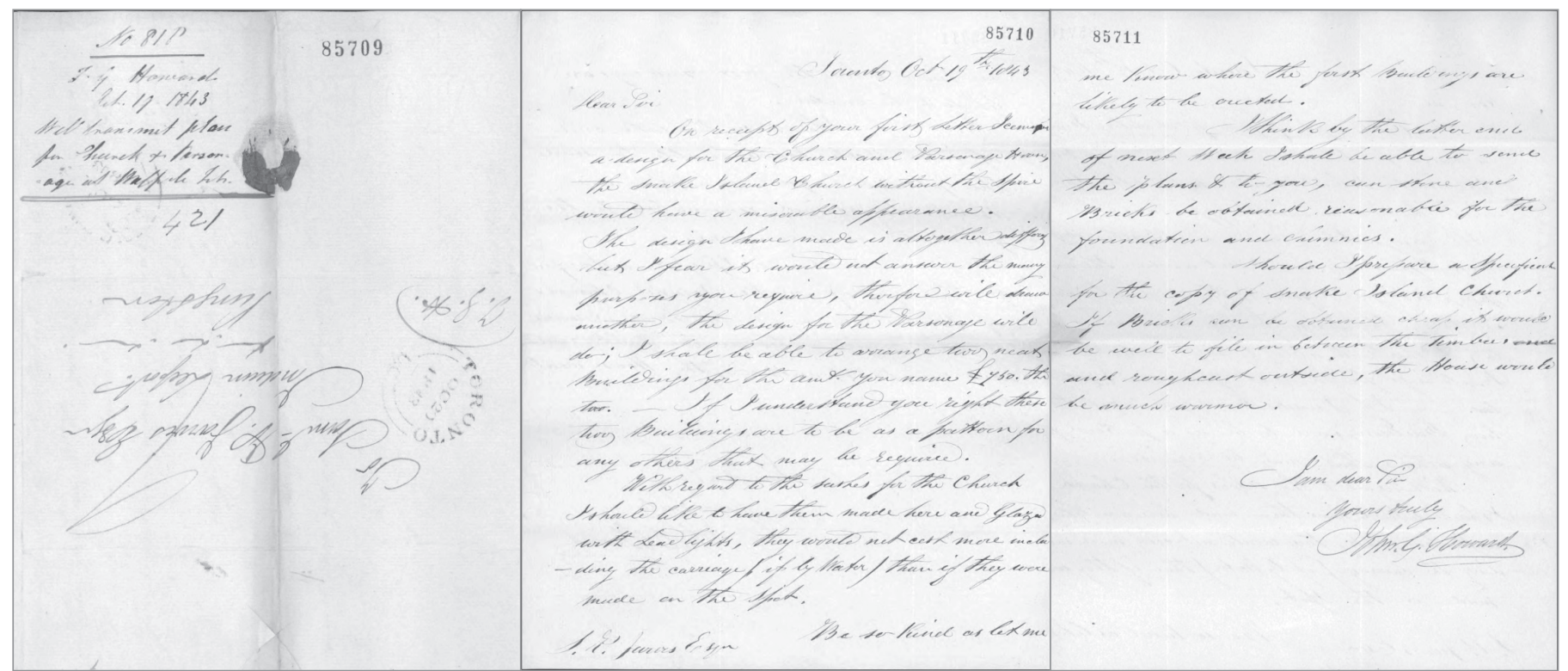

FIG. 23. HOWARD/JARVIS CORRESPONDENCE RE: SNAKE ISLAND CHURCH. | LIBRARY AND ARCHIVES CANADA, DEPARTMENT OF INDIAN AFFAIRS, JARVIS CORRESPONDENCE, VOL. 15, P. 74493-74494.

research in the area reveals, in the parish records of St. Paul's Anglican Church in Manitowaning, completed in 1849, mention of an original plan for the church to be built in stone. ${ }^{56}$

Howard's work on these mission churches was, as mentioned, through the Department of Indian Affairs, which was unabashedly biased in favour of the Anglican Church. ${ }^{57}$ The Department's office in Manitoulin was located in Manitowaning. ${ }^{58}$ Correspondence from Father Jean-Baptiste Proulx [1808-1881], credited for erecting the first mission church in Wikwemikong in 1838, "reported that Catholic Natives were prohibited from living near Manitowaning, that the Catholic mission was receiving no financial aid from the government for education, and that no government salary was being provided for him, as it was for the Anglican missionary." ${ }^{59}$ This concern was reiterated by Catholic Bishop Power, who "became increasingly concerned that the government's Indian Department was not only aiding the Anglican mission at Manitowaning but also openly discriminating against Proulx and the Catholic First Nations people at Wikwemikong." ${ }^{60}$

Based on this information, the author's theory is that Howard drew up designs for a stone church, for the Anglican mission at Manitowaning, and due to time constraints, as a building was needed imminently, and perhaps to conserve funds, Howard's design was never built. ${ }^{61}$ Church of England clergyman Frederick Augustus O'Meara [1814-1888] followed up in 1845 to raise funds and erect the wooden church of St. Paul's in Manitowaning, which is still standing. ${ }^{62}$

Described by Sir Richard Bonnycastle as "certainly the most interesting public building in Canada West," Christ Church, Tyendinaga, is located on South Church Lane in Deseronto. ${ }^{63}$ Howard records discussions for the church with a Mr. Givens, which began in December of 1842, but the plans for construction went well into
1843. ${ }^{64}$ MacRae and Adamson declare it both his "finest ecclesiastical monument" and "a cautious Perpendicular cloak on Georgian bones." 65 The church was built in local limestone. The original tower and spire (fig. 24) were destroyed by fire in 1906, which also damaged most of the interior and cracked the font; "the remainder of the church was faithfully reconstructed by the Mohawk." ${ }^{66}$ It follows Howard's usual plan for the most part, with the exception of the original tower, which had a gabled parapet and what appears to have been a foiled recessed ornament that was not repeated in the rebuild. The interior looking east displays the original screen, designed by Howard, which fortunately survived the fire. It is supported on clustered colonettes that mimic the grouped columns found at Jordan and Holland Landing, including the pier ring in the same unique position close to the moulded capitals. The three arches "once neatly framed the pulpit (entered through the Gospel arch), the altar (surmounted by the Creed, the Decalogue 


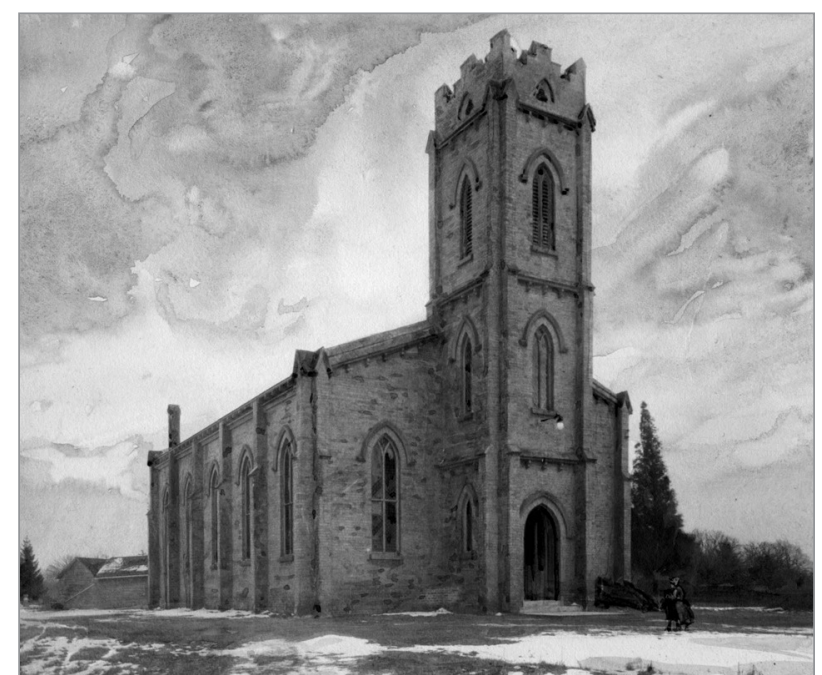

FIG. 25. ST. JOHN'S ANGLICAN CHURCH, YORK MILLS, PHOTOGRAPH COLOURED WITH WATERCOLOUR OF 1916. | COURTESY OF THE TORONTO PUBLLC LBRARY.

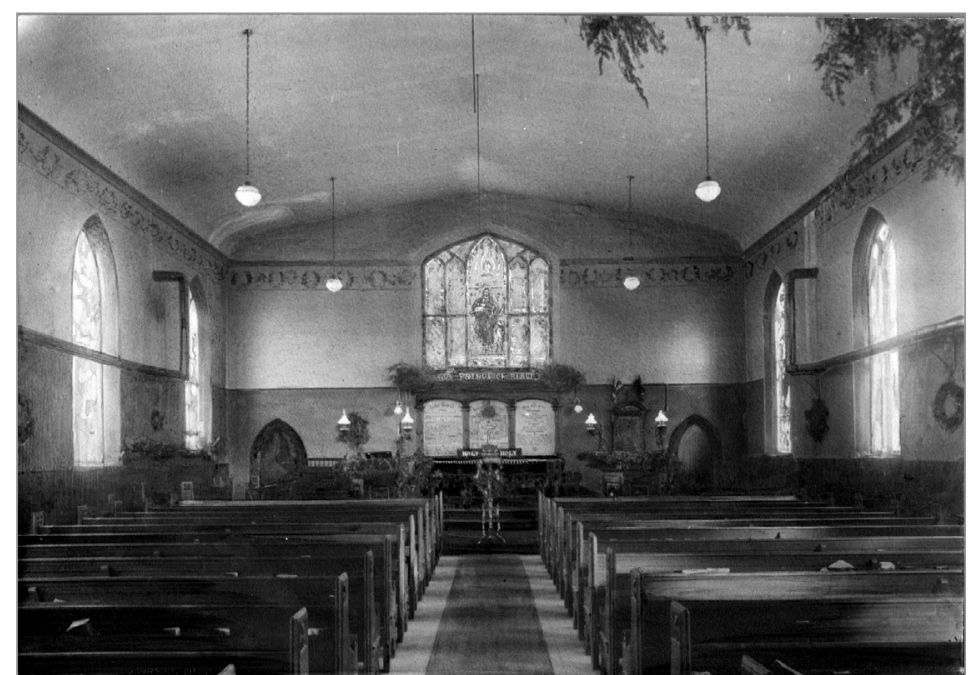

FIG. 26. INTERIOR YORK MILLS, PHOTOGRAPH COLOURED WITH WATERCOLOUR OF C. 1916. | COURTESY OF THE TORONTO PUBLIC LBRARY.

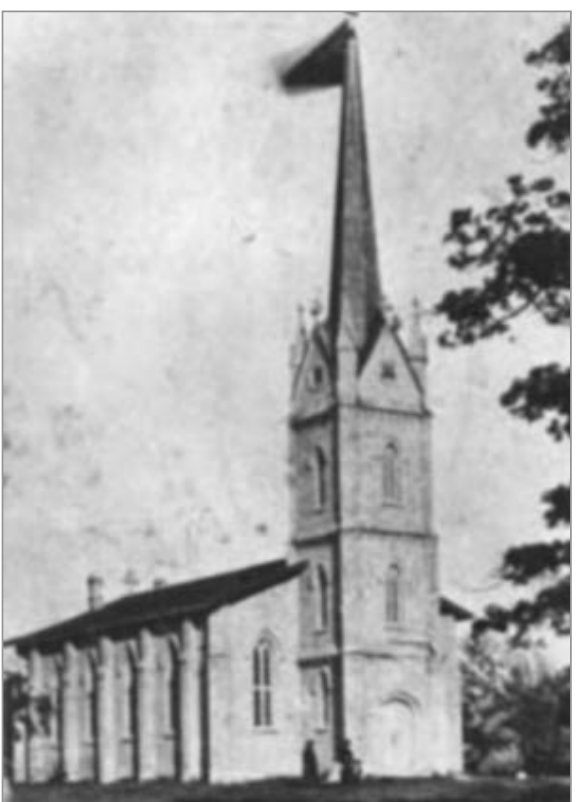

FIG. 24. CHRIST CHURCH, TYENDINAGA, ORIGINAL TOWER AND SPIRE. | [HTTP://WWW.PARISHOFTYENDINAGA.ORG/HISTORY.HTM].

and the Paternoster in Mohawk), and the reading desk (entered by the Epistle arch). The choir originally occupied the central pews of a west gallery, or choir loft." ${ }^{67}$ This gallery was subsequently removed, and an open timber roof was added in the rebuild after the fire.
There is reference in Howard's journals on July 7, 1842, and in Hallowed Walls to a Roman Catholic chapel in Barrie, since destroyed. ${ }^{68}$ In particular, Howard references a "Rev. Mr. Quenlin," which Morriss suggests may in fact be Father James Quinlan, a Roman Catholic priest who was in charge of the Medonte Township in the Simcoe District around $1840 .{ }^{69}$ Correspondence with the Roman Catholic Diocese for Barrie advises that there was only one Roman Catholic church in Barrie erected at that time, St. Mary's Catholic Church. Their website confirms the involvement of Father Quinlan, who writes on November 4, 1841: "In Barrie, we are prepared (as far as manual labor can go) for the erection of a fairly large frame building . . " "70 Their website also states in 1845 that two half-acre lots, numbers 127 and 128 on the north side of McDonald Street, were the site of the first church building in 1849-1850. It was a simple structure "constructed of a heavy timber frame sheeted on the outside, 50 feet long and 36 feet wide." 71

The year 1843 also saw the construction of St. John's Anglican Church (fig. 25), located at 19 Don Ridge Drive, York Mills, Toronto, a quintessential Howard church bearing all the architectural motifs Howard favoured (with an additional bay, to the usual four). There are corner buttresses finished with gables on the west front, in addition to the buttresses between each bay on the north and south sides. The interior has been greatly remodeled over the past century, but this image from 1916 gives some idea of the original layout (fig. 26). According to the instructions set out by John G. Howard, the original ceiling was designed to be "Lath, Plaster, float and set."72 There is also mention of a gallery "mortised to receive the cluster columns," a phrase that might suggest the same cluster columns as those designed for Snake Island, and extant at Jordan and Holland Landing. Designs for those columns are found in Howard's sketch for the interior furnishings (fig. 27). An oriel window surmounting "three panels for the Decalogue with 4 three quarter cluster columns, entablature and frieze" also could mimic the arrangement planned at Snake Island. Howard's exquisitely designed altar table, constructed in locally 


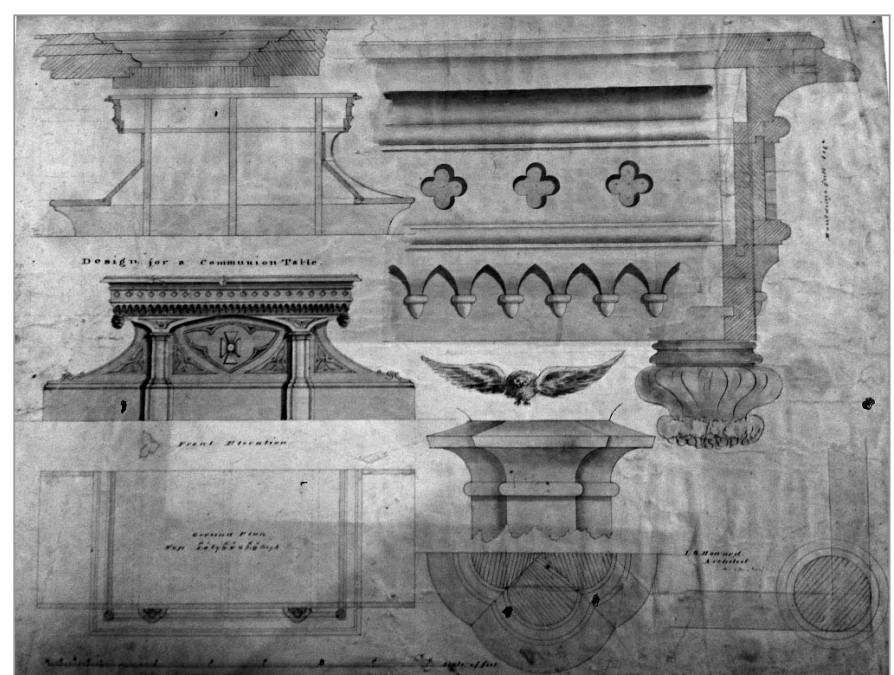

FIG. 27. HOWARD DRAWINGS FOR INTERIOR FURNISHINGS, YORK MILLS. | HOWARD FONDS, TORONTO REFERENCE LBRARY.

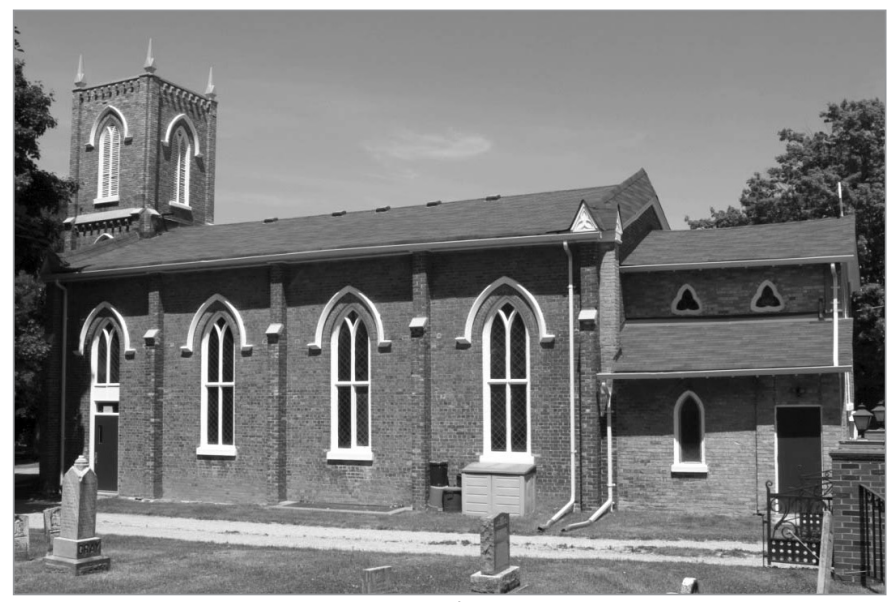

FIG. 29. CHRIST CHURCH, HOLLAND LANDING. | ALANA DUGGAN.

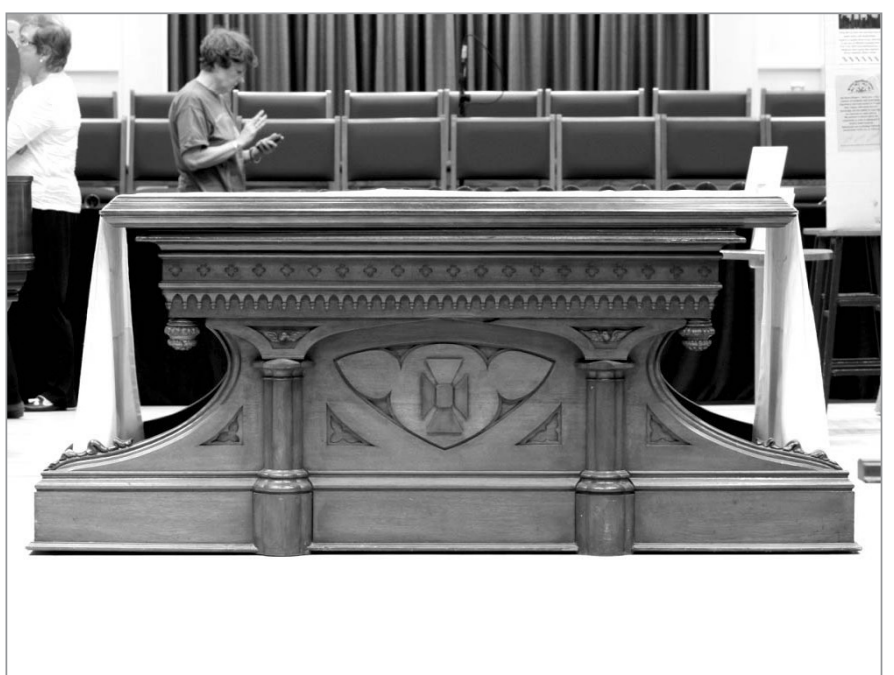

FIG. 28. ALTAR TABLE, YORK MILLS. | ALANA DUGGAN.

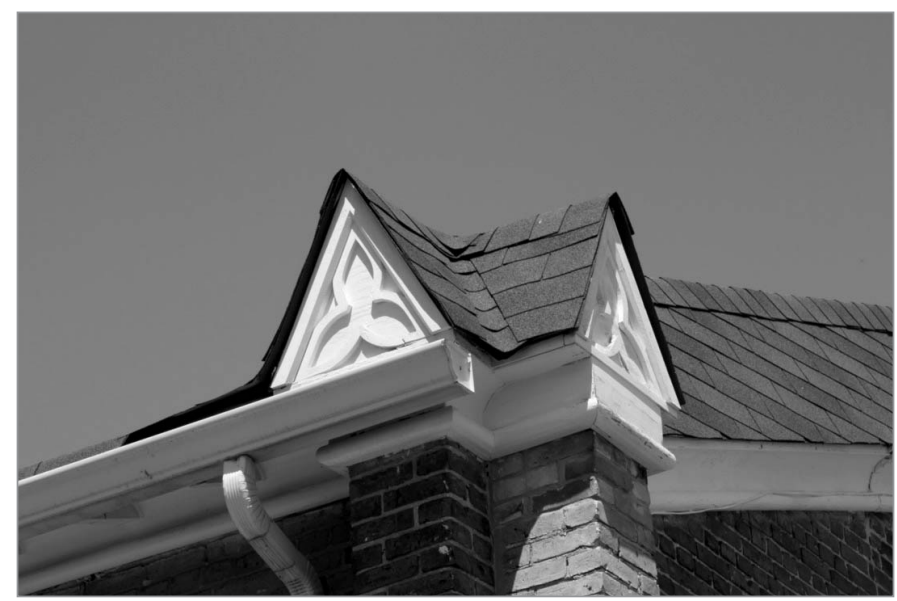

FIG. 30. DETAIL, HOLLAND LANDING. | ALANA DUGGAN. sourced black walnut, is still in use today (fig. 28). Miniature clustered columns, carved onto the face of the table, correspond with the gallery supports found at Jordan and Holland Landing, and the band of carved quatrefoils is paralleled in the pulpit at Jordan.

Located on Pine Street, east of the Brockville Courthouse, is St. Paul's Anglican (formerly Brockville Congregational), also designed by Howard, and consecrated on November 23, 1843. ${ }^{73}$ An 1843 article in
The Harbinger, a Congregational church magazine published in Montreal, writes: "The design, generously furnished by Mr. Howard, Architect, Toronto, without charge, is at once massive and chaste. Gothic in style, the walls are relieved with a series of buttresses, projecting between each of the five windows, and tapering to a point towards the roof." ${ }^{74}$ Robert Hill also attributes this church to Howard, but this is not corroborated in the architect's journals, nor in Hallowed Walls. ${ }^{75}$ It certainly has every appearance of a Howard construction, as exemplified in the layout with applied Gothic features and his distinctive parapet with the stepped crenellation and trefoil. The one anomaly, for a Howard church, "built of hewn stone from the quarry of William Freeland, Esq.," is that the tower buttresses are built on the corners, rather than on the angle. ${ }^{76}$ As stated by church records, the ceiling, the extension of the chancel, and the stainedglass windows were replaced in the west and east ends of the church; the nave, however, remains much as it was in 1852 . 


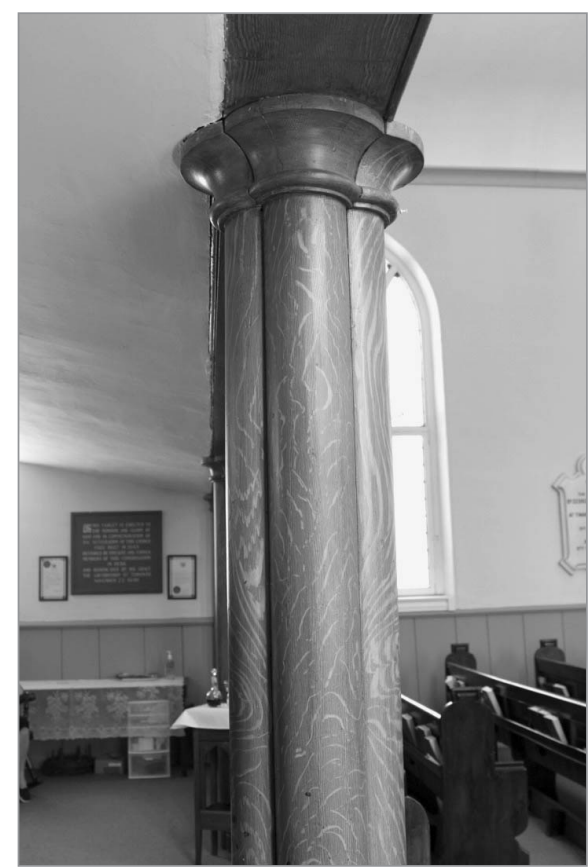

FIG. 31. GALLERY PIERS, HOLLAND LANDING. | ALANA dUGGAN.

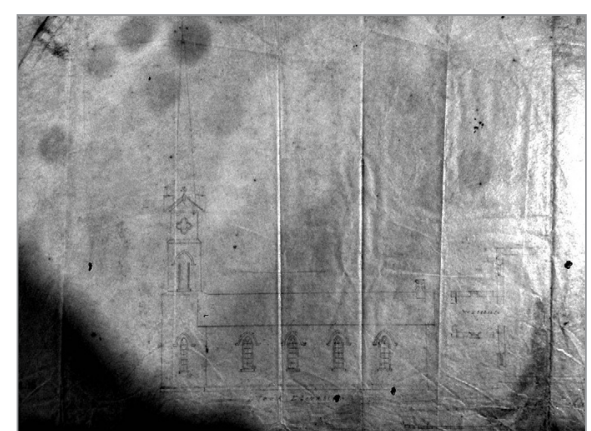

FIG. 32. SKETCH FOR LLOYDTOWN. | HOWARD FONDS, TORONTO REFERENCE LIBRARY.

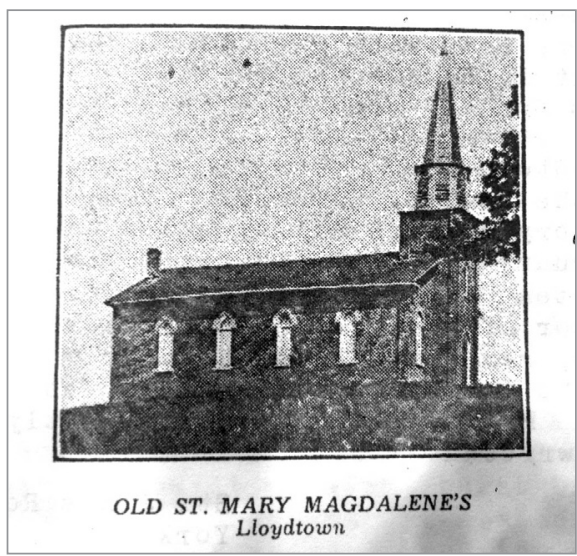

FIG. 33. ST. MARY MAGDALENE'S ANGLICAN CHURCH.| MARCHANT, ST. MARY MAGDALENE'S ANGLICAN CHURCH LLOYDTOWN, ONTARIO, P. 9.

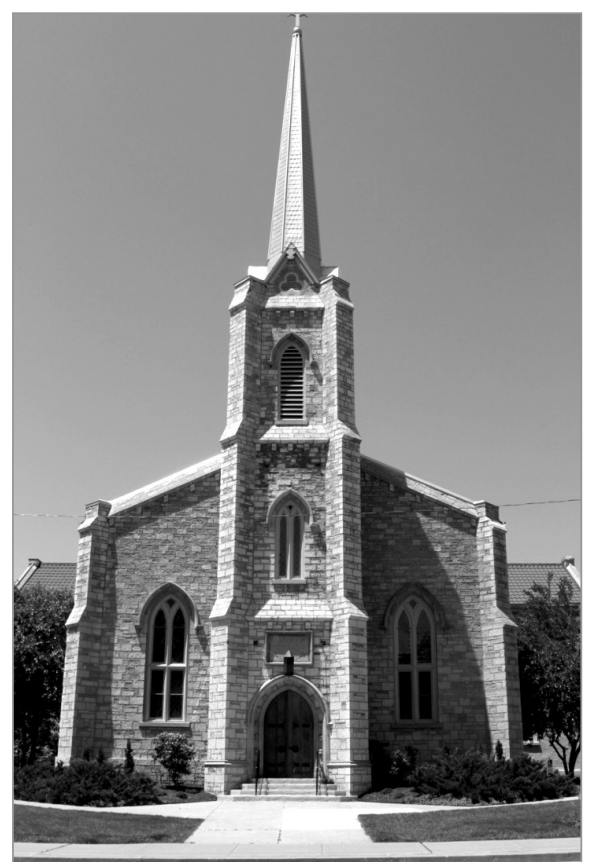

FIG. 34. ST. GEORGE'S ANGLICAN CHURCH, SAINT CATHARINES. | ALANA DUGGAN.

Christ Church (Anglican), Holland Landing, also built in 1843, is located at 110 Peter Street, Town of East Gwillimbury (fig. 29). It is an archetypal Howard church, embellished with a trefoil inside the buttress gables (fig. 30). An earlier photo of Holland Landing, in Hallowed Walls, shows the original stepped crenellation on the parapet, although without the trademark trefoil cutout. Inside, the ceiling is lathe and plaster. The interior, looking east, shows the chancel addition (from 1880), and looking west, there is a gallery supported by clustered columns (fig. 31). However, these piers are missing the moulded shaft ring found at Jordan, Snake Island, and Tyendinaga.

The church in Lloydtown must have been an important commission for Howard, as it is one of the few churches that he deemed fit to include in his memoirs. Work for the church is also recorded in his journals, in June and July of 1842 . There is a sketch associated with this commission in the

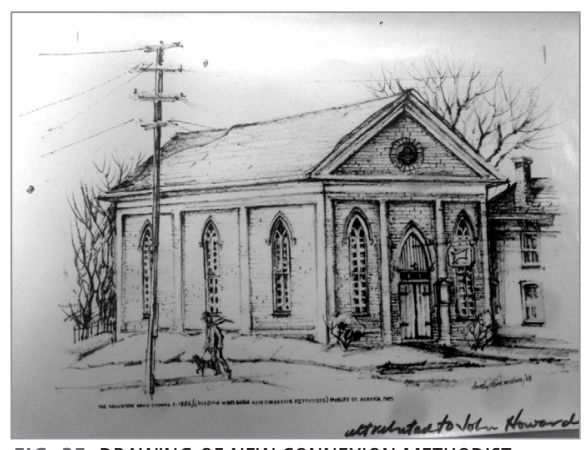

FIG. 35. DRAWING OF NEW CONNEXION METHODIST CHURCH, AURORA. I MACRAE AND ADAMSON FONDS, MCMASTER UNIVERSITY ARCHIVES.

Howard fonds at the Toronto Reference Library (fig. 32) that differs somewhat from the photograph (fig. 33) found in Victor Marchant's history of the church, mostly in the termination of the tower below the spire. The quatrefoil ornament is absent in the finished building. In the same text Marchant describes: "a new church building 50 feet long and 30 feet wide was built out of mud brick, plastered on the outside, and while the building was not yet completed, it was open for service on January 1st, 1843."77 Bishop Strachan, on his first episcopal visit to Lloydtown, remarked that it was "a neat mud church with a good spire." 78 Howard's church was demolished and replaced by a new building, in 1925, erected three quarters of a mile away in Schomberg. ${ }^{79}$

St. George's Anglican, in Saint Catharines, although a minor commission for Howard, is important to include because of the rector's request for the architect "to design a church tower free of charge" (fig. 34). ${ }^{80}$ Constructed in limestone, the tower and vestibule, with angled buttresses, were added to the existing building in 1844. The tower displays Howard's usual arrangement with three stages and bracketed setbacks, and a trefoil ornament at the top, but capped with a spire, rather than battlements. The pointed windows have horizontally terminated hood moulds. 
As the architectural field became even more competitive in the 1850 s with the arrival of new architects from overseas, Howard's architectural status and output decreased. ${ }^{81}$ As previously noted, he was nearing retirement by the middle of the decade. During these final years, there are only two churches, of uncertain attribution, recorded in connection to Howard. All Saints, Tyendinaga, near the Bay of Quinte, is one of them. Ontario Heritage Trust lists this church as a Howard construction and c. 1858 for the start date. ${ }^{82}$ MacRae and Adamson concur with this attribution, but place the date at 1851 . It houses "[ $t$ ] he best surviving example of the altar, as John Howard conceived it for many of his Upper Canadian Gothic churches." 83 The exterior does not look anything like a church designed by Howard, so perhaps he was only responsible for the altar design, or maybe the altar came from Christ Church, Tyendinaga, in the same parish. The second is the New Connexion Methodist Church, now converted to use as a naturopathic clinic. MacRae and Adamson suggest that this former Methodist church on Mosley Street in Aurora should be attributed to John Howard. This is noted in handwriting at the bottom of a sketch held in their fonds at McMaster University (fig. 35). Apart from the quatrefoil decoration and the lancet windows with hood moulds, this building is not characteristic of Howard's work. Moreover, the date of 1856 is problematic for a couple of reasons: it was the beginning of his retirement years, and why so late in his career, and after twenty plus years of Gothic Revival in Canada, would he employ what is essentially a Classical temple façade with pilasters in lieu of columns? The denomination of this church may again provide a potential explanation, at least in terms of the square plan. Methodists, like Congregationalists, preferred a square meetinghouse layout for their churches.

\section{CONCLUSION}

Although there are many question marks in John George Howard's body of ecclesiastical architecture, a discernable style has emerged from this preliminary investigation. There are many motifs, as discussed, that were consistently used by Howard over the years. These have been constructive in determining which buildings should be attributed to him and which should not, however the requirements of different patrons and denominations may have played a part in the designs that strayed from his usual plan. Moreover, the possibility for progression in his architectural approach should not be discounted. Howard's penchant for employing an architectural church formula may have been his solution for dealing with requests for free designs, and to manage the sheer volume of commissions he received during the peak of his career in the 1840s. Given that Howard had a substantial architectural practice designing domestic and public buildings, in addition to his work as a surveyor for the city and as drawing master at Upper Canada College, it is truly astonishing that he managed to complete this repertoire of church buildings, which often included the interior furnishings, over such a short period of time. It is therefore not surprising that he repeatedly resorted to employing his own architectural stylistic conventions, what was essentially a cookie-cutter approach to church building. Nevertheless, Howard did indeed leave an impressive legacy of churches, which remain significant monuments of early Gothic Revival architecture in Ontario.

\section{NOTES}

1. A debt of gratitude goes first and foremost to my supervising professor, Malcolm Thurlby, for his continued support, for suggesting Howard's churches as a subject ripe for research, and for encouraging me to submit the resultant paper to be considered for the Martin Eli Weil prize. Many thanks to Jessica Mace for her helpful revisions which improved the final draft of this paper. Thanks and appreciation are also due to the following people, who assisted considerably in the research of this paper: the staff at Colborne Lodgemost notably Elizabeth Nelson-Raffaele; the Archives at McMaster University; Sylvia Beben at the Jordan Historical Museum; Dean Jacobs at the Heritage Centre on Walpole Island; Bill Dennis, verger at St. John's, York Mills; the caretakers at Christ Church, Holland Landing; Veronika Reiser, Diane Netherway, and Brian Culp at St. John's, Jordan; John Rathbone, diocesan archivist, Anglican Diocese of Niagara; Linda Eckert at St. Paul's in Brockville; and the caretakers at All Saints, Tyendinaga.

2. Kalman, Harold D., 1994, A History of Canadian Architecture, vol. 1, Oxford University Press.

3. Arthur, Eric, 1986 [3 $3^{\text {rd }}$ ed.], Toronto: No Mean City, Toronto, University of Toronto Press. Contribution to Howard's practice by his wife, Jemima Frances Meikle, who "often under[took] the tedious work of copying specifications," should not go unnoticed.

4. The validity of this new moniker was challenged at the Exhibition of the Toronto Society of Artists and Amateurs in 1834, but never fully resolved. He later claimed to be a descendent of Thomas Howard, fourth Duke of Norfolk, and took great pride in this dubious heritage. See: Lowrey, Carol D., 1981, "The Society of Artists and Amateurs, 1834: Toronto's First Art Exhibition and its Antecedents," Canadian Art Review, vol. 8, no. 2, p. 104

5. Firth, Edith G., n.d., "Howard, John George," Dictionary of Canadian Biography, vol. 11, n.p., University of Toronto/Université Laval, 2003, [http://www.biographi.ca/en/bio/howard john_george_11E.html], accessed March 2, 2016.

6. Vattay, Sharon, 2001, Defining "Architect" in Nineteenth-century Toronto: The Practices of John George Howard and Thomas Young, unpublished Ph.D. dissertation, University of Toronto. 
7. Howard's journals in seven volumes were edited and annotated by Shirley Morriss in 1980.

8. Lowrey, "The Society of Artists and Amateurs," footnote no. 25.

9. These documents are housed in the Baldwin Collection at the Toronto Reference Library.

10. Arthur, Toronto: No Mean City, p. 251.

11. Ibid.

12. Wright, Janet, 1984, "Architecture of the Picturesque in Canada," Canada's Historic Places, Parks Canada Agency, Electronic Edition.

13. Curl, James Stevens, 2006, "Commissioners" Churches," A Dictionary of Architecture and Landscape Architecture, Oxford University Press, [http://www.oxfordreference.com. ezproxy.library.yorku.ca/view/10.1093/ acref/9780198606789.001.0001/acref9780198606789-e-5453\&gt], accessed May 2016; Kalman, A History of Canadian Architecture, p. 268.

14. Wright, "Architecture of the Picturesque in Canada," p. 55. This quote references Howard's design for a gatehouse to Upper Canada College, in 1834, but it could equally apply to the requirements of his church patrons.

15. Gibbs, James, 1728 [3 $3^{\text {rd }}$ ed], Gibbs' Book of Architecture: An Eighteenth-century Classic, London, Dover Publications; Gibbs, James, 1753, Rules for Drawing the Several Parts of Architecture..., London, printed for W. Innys, J. Richardson, P. Knapton, R. Manby, and H.S. Cox, [http://www3.nd.edu/ archlib/RareBooks/Gibbs-Park-folio-18.pdf], accessed June 2016.

16. Grose, Francis, 1791, The Antiquities of Ireland, Second Volume, London, printed for S. Hooper, Archive.org, accessed January 2016.

17. MacRae, Marion and Anthony Adamson, 1975 Hallowed Walls: Church Architecture of Upper Canada, Toronto, Clarke, Irwin \& Co. Ltd.

18. Vattay, Defining "Architect," p.79. Vattay notes that in 1833, Howard designed (or altered) for various clients no fewer than eight residential projects, six public or institutional buildings, and three commercial structures. Sir John Colborne was lieutenant governor of Upper Canada from 1828 to 1838. Archdeacon Strachan became Bishop Strachan in 1839.

19. Arthur, Toronto: No Mean City, p. 74

20. Id., p. 74-79. The Howard home would have been well outside the city boundaries at that time, which formed a rectangle bordered by Parliament, Bathurst, Bay Shore streets to the south, and Dundas to the north.

21. Id., p. 68

22. Pilon, Henri, 2003, "Elmsley, John" [18011863], Dictionary of Canadian Biography, vol. 9, n.p., University of Toronto/Université Laval, [http://www.biographi.ca/en/bio/elmsley_john_1801_63_9E.html], accessed January 2016.

23. See MacRae and Adamson, Hallowed Walls, p. 98-99. There are no footnotes nor bibliography confirming this claim in their book.

24. For example, there is no mention of it on the list of Howard's works in Eric Arthur's No Mean City, p. 251, nor is it listed in Robert G. Hill's Biographical Dictionary of Architects in Canada 1800-1950. It is unfortunate that MacRae and Adamson provide no documentation in the form of footnotes or bibliography however, some of the missing documentation for Hallowed Walls can be found in the fonds at McMaster University Archives.

25. MacRae and Adamson, Hallowed Walls p. 99. In 1853, Elmsley donated a portion of his Clover Hill property for the building of a parish church on St. Joseph Street. See Robertson, John Ross, 1868, Sketches in City Churches, Toronto. J. Ross Robertson. The first commission for the design of this church went to William Hay, and the result was the construction of St. Basil's Church and college in 1856. See [http://www.greatpast.utoronto. ca/bios/history38.asp], accessed January 2016.

26. [http://www.historicplaces.ca/en/rep-reg/ place-lieu.aspx?id=1346], accessed April 2016. Historic Places lists the architect as John W. Howard. See MacRae and Adamson, Hallowed Walls, p. 92.

27. MacRae and Adamson, ibid.

28. Vattay, Defining "Architect," p. 162.

29. Kalman, A History of Canadian Architecture, p. 178.

30. "Spiritual Toronto," Virtual Exhibits, City of Toronto website, [https://www.toronto.ca/ explore-enjoy/history-art-culture/museums/ virtual-exhibits/textures-of-a-lost-toronto/ spiritual-toronto/]. See also Hill, Richard, 2009, "Howard, John George," Biographical Dictionary of Architects in Canada. [http://dictionaryofarchitectsincanada.org/node/1532], accessed March 2016.

31. Morriss, Shirley (ed.), 1980, The Journal of John George Howard 1833-49, Toronto,
Ontario Heritage Foundation, Ministry of Citizenship and Culture, Book 2, vols. 34

32. MacRae and Adamson, Hallowed Walls, p. 94.

33. Iron, Candace and Malcolm Thurlby, 2010, "John G. Howard's St. James's Anglican Church, Dundas," Raise the Hammer website, n.p., [http://raisethehammer.org/article/1113], accessed June 2016.

34. MacRae and Adamson, Hallowed Walls, p. 94.

35. Id., p. 97-98.

36. Scadding, Henry, D.D., 1873, Toronto of Old: Collections and Recollections, Toronto, Adam Stevenson \& Co., Archive.org, p. 406

37. Britton, John, 1826, The Architectural Antiquities of Great Britain: of Various Ancient English Edifices. Volume 5, London, Longman, Hurst, Rees, Orme, Brown and Green.

38. Britton, John, 1829, The History and Antiquities of the Abbey and Cathedral Church of Gloucester, London, Longman, Hurst, Rees, Orme, Brown and Green, Archive.org, plate 5.

39. Toronto Reference Library, Baldwin Room, John George Howard fonds, accessed on several occasions in 2016 and 2017.

40. Iron and Thurlby, "John G. Howard's St. James's Anglican Church, Dundas," op. cit.

41. Strachan, Lord Bishop John, 1846 [3 $3^{\text {rd }}$ ed.], A Journal of the Visitation to the Western Portion of His Diocese, printed for The Society for the Propagation of the Gospel. From Bishop Strachan's visit to Dundas, dated September 29, 1842: "The only Anglican church of any stature actually seen by John Strachan before he became archdeacon of York was the Cathedral at Quebec City, which echoed the Neo-Classic style in vogue in Britain." MacRae and Adamson, Hallowed Walls, p. 278.

42. MacRae and Adamson, id., p. 143.

43. Reverend G.M. Armstrong was the first clergyman to take up his residence at St. John's, Jordan, sometime before July 1840 . See St. John's Congregation, 1966, History of St. John's Church, Jordan and the Parish of Louth, Beamsville, Rannie Publications.

44. I am grateful to Malcolm Thurlby for confirming that this feature is indeed unusual, which strengthens the links to Howard in churches where it was employed.

45. Letter from Reverend George Armstrong to J.G. Howard dated July 12, 1843. Anglican Diocese Archives at Christchurch cathedral, Hamilton, retrieved Thursday April 27, 2017. 
46. Id.

47. Morriss, The Journal of John George Howard, p. 215.

48. Library and Archives Canada, 1837-45, Department of Indian Affairs, Jarvis Correspondence, Snake Island, Lake Simcoe, RG 10, vol. 15, p. 74493-74494, digitized order received February 19, 2016.

49. Morriss, The Journal of John George Howard, p. 2122.

50. Hall, Tony, 1990, "Native Limited Identities and Newcomer Metropolitanism in Upper Canada, 1814-1867," in Keane and Read (eds.) Old Ontario, op. cit., p. 158.

51. Morton, Graeme and David A. Wilson (eds.), 2013, Irish and Scottish Encounters with Indigenous Peoples: Canada, the United States, New Zealand, and Australia, Montrean and Kingston, McGill-Queen's Press - MQUP.

52. Krasowski, Sheldon, 1998, A Numiany (The Prayer People) and the Pagans of Walpole Island Frist Nation: Resistance to the Anglican Church, 1845-1885, master's thesis, Canadian Studies/Native Studies, Trent University, Oshawa, ON, p. 74-75. Neither the Huron Anglican Diocese archives nor the Heritage Centre on Walpole Island have any record of this church.

53. Howard, John G., 1885, Incidents in the Life of John G. Howard, Esq. of Colborne Lodge, High Park, Near Toronto: Chiefly Adapted from his Journals, Toronto, s.n.; PAC, RG 10, Records Relating to Indian Affairs, Jarvis Correspondence 1837-1845, vol. 132.

54. MacRae and Adamson, Hallowed Walls, p. 102; Vattay, Defining "Architect," p. 171. It is worth noting here that Vattay also mentions a communication between Howard and A.F. Atkinson, rector of St. George's Church, Saint Catharines, dated October 22, 1842, in connection with the Manitoulin church. St. George's was an Anglican church.

55. Donnelly, Joseph P., 1976. "Point, Nicolas," Dictionary of Canadian Biography, vol. 9, n.p., Toronto and Quebec, University of Toronto / Université Laval, [http://www.biographi. ca/en/bio/point_nicolas_9E.html], accessed March 2016.

56. Diocese of Algoma, 2015, The Anglican Churches of Manitoulin Island, n.p., [http:// www.dioceseofalgoma.com/UploadedFiles/ file/Job \% 20 Postings/Manitoulin $\% 20$ Island \% 20Profile \% 20 Dec \% 202015\% 20 (reduced).pdf], accessed March 2016; Douglas and Peter Richardson do little to help clarify the matter in their book, Canadian Churches, which includes a photograph of St. Paul's Anglican church with a brief description, but erroneously lists its location as both Wikwemikong and Manitowaning. Richardson, Douglas Scott and Peter Richardson, 2007, Canadian Churches: An Architectural History, Richmond Hill, ON, Firefly Books Ltd.

57. For more information on this partiality toward the Anglicans, see Morton and Wilson, Irish and Scottish Encounters, p. 198.

58. The office for Indian Affairs was located in Manitowaning. See: Island of Great Spirit: The Legacy of Manitoulin, Manitoulin Museums Foundation, The Ontario Visual Heritage Project Team, [http://www.visualheritage.ca/ manitoulin/ManitoulinCourseGuide.pdf], p. 26.

59. Morton and Wilson, p. 199-200.

60. Id., p. 200.

61. Diocese of Algoma, "The Anglican Churches of Manitoulin Island," op. cit.

62. Millman, Thomas R., "O'Meara, Frederick Augustus," in Dictionary of Canadian Biography, vol. 11, n.p., Toronto and Quebec, University of Toronto/Université Laval, 2003, [http://www.biographi.ca/en/bio/o_meara_ frederick_augustus_11E.html.], accessed April 26, 2016.

63. MacRae and Adamson, Hallowed Walls, p. 101.

64. Morriss, The Journal of John George Howard, p. 309. Mr. Givens refers to the Anglican priest Saltern Givins, who served as a missionary to the Mohawk natives of the Bay of Quinte from 1833 to 1849 .

65. MacRae and Adamson, p. 102.

66. Parks Canada, "Christ Church, Her Majesty's Chapel Royal of the Mohawk National Historic Site of Canada," [http://www.historicplaces. ca/en/rep-reg/place-lieu.aspx?id=13573\& \&id $=2780 \& \mathrm{~h}=$ Tyendinaga], accessed March 2016 .

67. MacRae and Adamson, p. 102.

68. Id., p. 94.

69. Morris, The Journal of John George Howard, p. 254.

70. [http://stmarysbarrie.com/history.aspx], accessed June 2016.

71. Id.

72. Howard files, "Specifications of the sundry works necessary to be done in erecting a Church at York Mills," St. John's York Mills Archives, photocopy of original document.
73. The Harbinger, vol. 2, no. 12 (December 15, 1843) Montreal, Lovell \& Gibson. Early Canadiana online, [http://eco.canadiana.ca/ view/oocihm.8_04455_24/7?r=0\&s=1], p. 182

74. Ibid.

75. Hill, Robert G., 2009, "Howard, John George," Biographical Dictionary of Architects in Canada, n.p., [http://dictionaryofarchitectsincanada.org/node/1532], accessed January 2016. The website for the church, now St. Paul's Anglican, attributes the design to a "L.G. Howard . . . under the supervision of Benjamin Chaffey Jr., [http://www.stpaulsbrockville.ca/history-c24.php], accessed March 2016.

76. The Harbinger, op. cit., p. 182.

77. Marchant, Victor, 1971, St. Mary Magdalene's Anglican Church Lloydtown, Ontario: One Hundred and Thirty Years in Retrospect 18401870, Lloydtown, The Church, p. 8.

78. Bull, William Perkins, 1937, From Strachan to Owen: How the Church of England Was Planted and Tended in British North America, Toronto, The Perkins Bull Foundation, George J. McLeod Ltd., p. 202.

79. Marchant, St. Mary Magdalene's, p. 15.

80. Id., p. 280.

81. Vattay, Defining "Architect," p. 163.

82. Ontario Heritage Trust, "All Saints Anglican Church (Upper Church)," Ontario Places of Worship, [http://www.heritagetrust.on.ca/en/ index.php/places-of-worship/places-of-worship-database/search/powresults/details?id= 3292\&backlinkslug =search \&fields \% 5Bprope rty_name $\% 5 \mathrm{D}=\mathrm{All}+$ Saints], accessed March 2016.

83. MacRae and Adamson, Hallowed Walls, p. 97. 